Article

\title{
Protected Areas: Geotourist Attractiveness for Weekend Tourists Based on the Example of Gorczański National Park in Poland
}

\author{
Krzysztof Widawski ${ }^{1, *}$, Piotr Oleśniewicz ${ }^{2}$, Agnieszka Rozenkiewicz ${ }^{1}{ }^{\circledR}$, Anna Zaręba $^{1}$ and \\ Soňa Jandová ${ }^{3,4}$ \\ 1 Institute of Geography and Regional Development, University of Wrocław, pl. Uniwersytecki 1, \\ 50-137 Wrocław, Poland; agnieszka.rozenkiewicz@uwr.edu.pl (A.R.); anna.zareba@uwr.edu.pl (A.Z.) \\ 2 Faculty of Physical Education, University School of Physical Education in Wrocław, al. Ignacego Jana \\ Paderewskiego 35, 51-612 Wrocław, Poland; piotr.olesniewicz@awf.wroc.pl \\ 3 Faculty of Mechanical Engineering, Technical University of Liberec, Studentská 2, \\ 46117 Liberec, Czech Republic; sona.jandova@tul.cz \\ 4 Department of Sports and Outdoor Activities, College of Physical Education and Sport PALESTRA, \\ Slovačíkova 400/1, 19700 Prague 19, Czech Republic \\ * Correspondence: krzysztof.widawski@uwr.edu.pl; Tel.: +48-71-37-59-579; Fax: +48-71-343-5184
}

Received: 1 February 2020; Accepted: 23 March 2020; Published: 25 March 2020

\begin{abstract}
The aim of the publication was to assess the geotourist attractiveness of protected areas in Poland among weekend tourists based on the example of Gorczański National Park. The park location near urbanized areas makes it an attractive field for research on weekend tourism development. The tourist potential of the park is presented, starting from geological aspects and geotourist values. Then, the tourist potential was analysed, with a focus on geotourist resources, which include tourist trails and didactic routes. The tourist traffic volume was also examined. On the basis of legal documents, such as nature conservation plans, threats related to tourism development in protected areas were presented as indicated by park managers. In accordance with the Act on Nature Conservation, the threats are divided into four groups: internal existing and potential threats and external existing and potential threats. The tourists' opinion on the geotourist attractiveness of the park was investigated with surveys conducted during selected weekends significant in the context of tourist traffic volume. Thus, a profile of people visiting the park for short stays was obtained, as well as their assessment of the tourist resources of the area, with particular emphasis on geotourist values.
\end{abstract}

Keywords: geotourism; protected areas; weekend tourism; tourists' opinion; national parks

\section{Introduction}

The very idea of nature conservation appeared in 1872, when the first national park, Yellowstone, was established [1,2]. Since then, protected areas have been exceptionally attractive for tourist penetration. Notably, the first national park in the world's history is still considered a most appealing destination because of its geotourist character [3]. For many decades, tourism and nature conservation have coexisted in the tourist space, as highlighted by the subject literature [4]. The popularity of tourism based on natural resources, both animated and inanimate, increased at the turn of the last century [5-9]. Such an increase can always have, and usually has, a twofold impact on the area itself, its resources, and its environment. On the one hand, it translates into raising environmental awareness of tourism participants. On the other hand, the uncontrolled presence of tourists itself may pose a threat to any kind of natural resources protected by the national park institution, including the inanimate ones [10]. These two aspects are indicated in many literature sources. Together with the growing 
tourist awareness of the need to protect inanimate natural resources, the need for geoconservation was pointed at. The main assumption of this idea is the demand for proper management of the geological heritage, substantial for both aesthetic and educational reasons [11,12]. It should be accompanied by appropriate promotion of the values themselves as well as adequate attitudes $[13,14]$. This standpoint is an essential part of a broader approach to the protection of geoheritage, which should be reflected in properly defined geoconservation strategies [15-18].

However, the role of tourism should not be limited to minimizing the possible losses associated with its presence in a space requiring protection due to the uniqueness of its resources. Tourism can and should contribute to the protection of natural heritage, as pointed out by many authors [1,19-23]. The key to success is proper environmental education, which should bring definite results and give impetus for further actions. One of the basic effects should be an appropriate attitude of the local community when using the natural resources of the region [24]. A sustainable approach is fundamental, so that resources can be utilized in a long perspective [25-27]. To this end, the region should ensure that its tourist infrastructure is properly developed. Correct handling of tourism is often the key to success, as implied by Bushell [28] or Priskin [29]. In their action strategy, regional authorities should take into account the active role of the local community. Only then it is possible to preserve resources in a relatively unchanged form [30,31], especially if the participation of the local community in the protection translates into specific income related to the development of tourism in the protected area, usually located in so-called marginal areas, away from large industrial or service centres [32].

Protected areas are attractive for many contemporary forms of tourism. For years, they have been associated, not without reason, with green tourism, ecotourism, or nature tourism [4,19-23]. This is natural, at least because of the specific tourist resources assigned to these types of tourist spaces. In addition, other forms of active or specialized tourism, characteristic of the natural environment, are also developing. These include skiing, cycling, and horse-riding tourism, as well as mountain climbing and speleological tourism, requiring specialized knowledge and skills. Against this background, the last three decades have seen a relatively new form of tourism, geotourism, also present in protected areas.

The concept was defined in the middle of the last decade of the previous century. Hose [33-37] was among its first investigators. Hose and Vasiljević ([38], p. 27) pointed at geotourism as a form that constitutes "the provision of interpretive and service facilities enabling tourists to acquire knowledge and understanding of the geology and geomorphology of a site (including its contribution to the development of the Earth sciences) beyond the level of mere aesthetic appreciation". The geological aspect in the development of this form of tourism is important [38]. The context of sustainable development, which should accompany this form of tourism, was highlighted by Newsome and Dowling [39] in their understanding of geotourism as drawing its attractiveness from the heritage of the inanimate nature of the tourist region.

A natural place for the development of geotourism seems to be protected areas, by definition offering nature preserved in an unchanged or barely changed form. The subject literature [11,40] indicates nature reserves, landscape parks, natural parks, but above all, national parks. Owing to their resources, their location as usually far from urbanized areas, and their general attractiveness, national parks are visited by a greater number of tourists year after year. Increased tourist traffic can pose a threat to the protected nature in the park area [41-45]. In the case of inanimate nature, usually trampling, collecting, changes in soil structure, and erosion are mentioned [41,46-56]. Therefore, for the proper functioning of the national park and management of its resources, it is crucial to investigate all forms of tourist traffic occurring in its area [15-18,57,58].

The main aim of this article was to present the tourist attractiveness of Gorczański National Park in the opinion of its weekend visitors. For this purpose, a questionnaire was carried out in three selected periods between 2016 and 2017; responses were collected from 244 properly surveyed tourists who visited the park over a weekend (details are described in the Section 3). Since the publication focuses primarily on the geotourist aspect and its evaluation among the park visitors, geotourist values were chosen to be presented first, starting with a brief introduction to the Gorce Mountains geology. Next, 
we describe the elements of infrastructure that simultaneously constitute inanimate nature resources in a linear form, such as tourist trails and didactic routes. The analysis of the opinions of weekend tourists visiting the park is preceded by a short presentation of the volume of tourist traffic recorded in the second decade of the 21st century. Its increase in recent years clearly shows the potential of Gorczański National Park, one of the most interesting mountain national parks of Poland, as a tourist destination. Its location near one of the country's major agglomerations, Kraków, as well as the Silesian conurbation, makes it an almost natural weekend tourism destination in this part of the country, and thus an interesting field of research on the geotourist attractiveness of this protected area in the opinion of both ordinary tourists and those with the "geo-" prefix.

\section{Study Area}

\subsection{Gorczański National Park Location}

Gorczański National Park is entirely located in the Gorce Mts., surrounded by the Beskid Wyspowy Mts. in the north, the Beskid Sadecki Mts. in the east, the Orawa-Nowy Targ Basin in the south, and the Orawa-Jordanów Foothills in the west. The park occupies 14\% of the range area, which is about $500 \mathrm{~km}^{2}$ [59].

The Gorce Mts. is a homogeneous mountain range belonging to the intermediate mountains. The landscape of Gorczański National Park involves primarily forests and glades. Slightly more than half of the range rises above $600 \mathrm{~m}$ a.s.l. Relatively few summits exceed $1000 \mathrm{~m}$ a.s.l. The highest peaks include Turbacz (1310 m a.s.1.), Jaworzyna Kamienicka (1228 m a.s.1.), and Kiczora (1282 m a.s.1.). The structure of the Gorce Mts. is distinctive. Six ridges, separated by V-shaped river valleys, spread out from Turbacz in different directions. The two longest ridges spread out in opposite directions: south-east and north-west.

The park was founded on 1 January 1981 by the Ordinance of the Council of Ministers of 8 August 1980 on the creation of Gorczański National Park [60]. In 1988, the Minister for Agriculture, Forestry, and Food Economics incorporated 805 ha of farmland forests. The park involves enclaves: the eastern slopes of Bardo; northern slopes of Jaworzyna Ponicka; Kędzierski forest; Mechów forest; and Morgi Czajkowskie forests. The area of the park currently covers 7019 ha [61] (Figure 1).

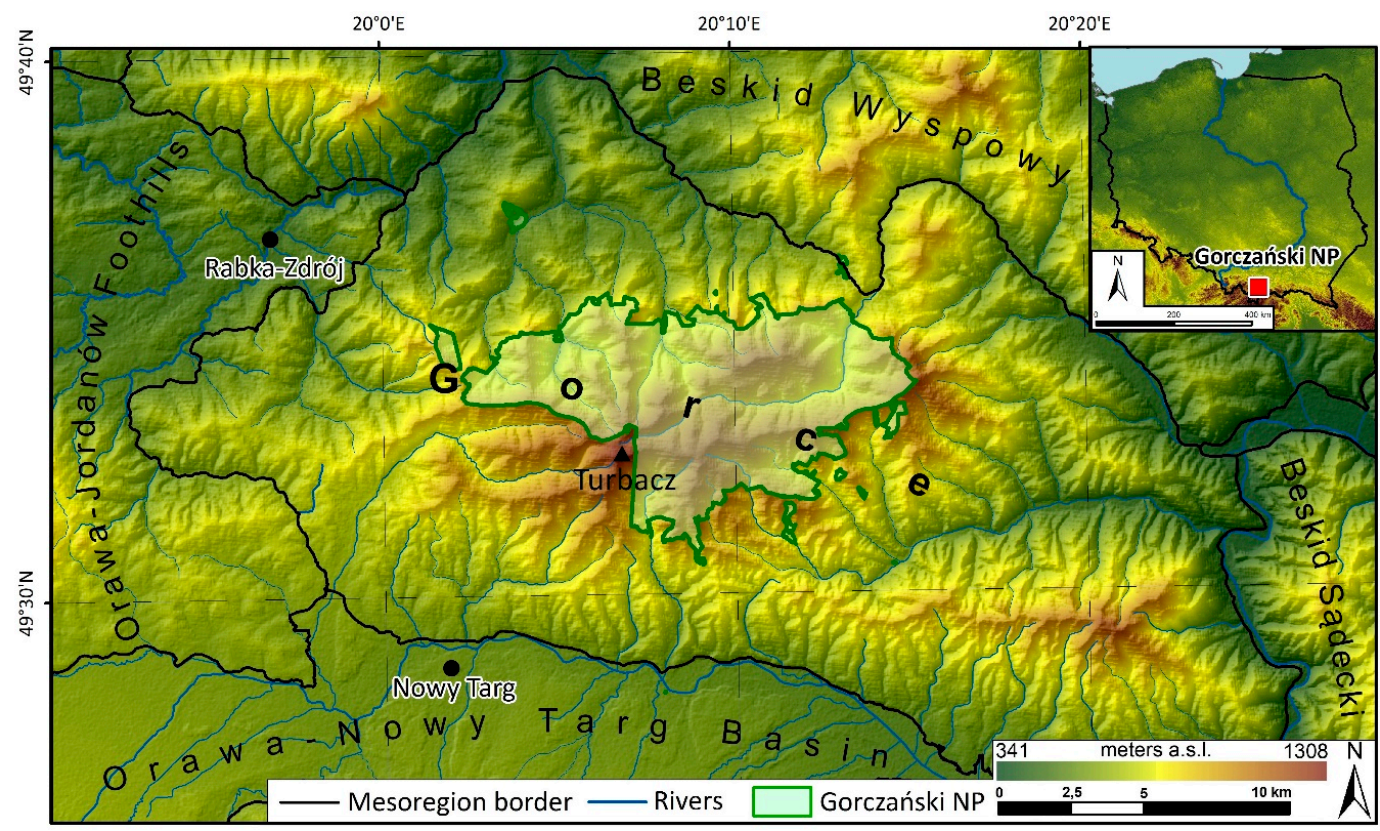

Figure 1. Gorczański National Park. 


\subsection{Tourist Attractiveness of Gorczański National Park}

Tourist attractiveness refers to tourist resources, tourist infrastructure, and communication accessibility [62]. The main role in geotourism is undoubtedly played by the related values generating tourist traffic in specific regions. The Polish subject literature divides tourist resources into two main groups: natural and cultural [61-66]. These constitute a group of sightseeing values [67]. For the purposes of this research, the group of natural values is particularly important; they are a natural reservoir of geotourist values. It is worth emphasizing that not all elements of animated or inanimate nature can be regarded a tourist value. Only those that meet certain conditions may be included in this group:

- they are big enough to be recognizable in the landscape;

- they arouse interest among tourists;

- they are inherently resistant to tourist traffic in their immediate vicinity;

- $\quad$ they are properly adapted to the reception of tourist traffic [67].

A more detailed division of natural values introduces the following three main groups:

- Values that are not influenced by human activity. These are caves and grottoes, groups of rocks, valleys and gullies, erratics, scenic viewpoints presenting geologically and geomorphologically attractive landscapes, and among the elements of an animated nature-peculiarities of fauna and flora.

- Values whose character and shape have been significantly influenced by human activity. This group includes primarily assets of an animated nature, such as historic parks, botanical, and zoological gardens.

- Values of surface character. Human activity did not affect their nature or shape. These are protected areas that constitute a reservoir of many assets of an animated and inanimate nature, protected because of their unique character. In this group, the most important type is national parks, which in Poland have the status of the highest form of nature conservation.

At this point, it is worthwhile to take a brief look at the potential of tourist resources of an inanimate nature in one of the most attractive mountain national parks of Poland: Gorczański National Park.

\subsection{Geology of Gorczański National Park}

The Gorce Mts. range is a part of the Outer Western Carpathians. The Gorce Mts. are built of flysch rocks of the Magura nappe-sandstones, conglomerates, and shales of the Early and Middle Eocene $[68,69]$. Structurally, the Magura nappe is the uppermost tectonic element of the Polish Outer Carpathian wedge [70]. Thick-bedded layers of sandstones sedimented in Palaeocene and Eocene (ca. 65-37.5 million years ago) constitute the dominant complex, with a thickness exceeding $2000 \mathrm{~m}$. The central part of the mountain chain is mainly built of Magura sandstones and of conglomerates. These rocks build both the ridge parts of the Gorce Mts. and their highest peak, Turbacz (1310 m a.s.1.), and also form tors of original shapes. The border parts of Gorczański National Park are built of sandstones and shales, with numerous valleys, passes, and depressions resulting from erosion processes [71].

The unique geological character of the Gorce Mts. is typical, especially for its northern part, where Gorczański National Park was established. This is determined primarily by the variety and degree of exposure of the Magura nappe rocks occurring in the Gorce Mts. area. The unique geological character of the Gorce Mts. is typical especially for its northern part, where Gorczański National Park was established [72]. This is determined primarily by the variety and degree of exposure of the Magura nappe rocks occurring in the Gorce Mts. area (Figure 2). 


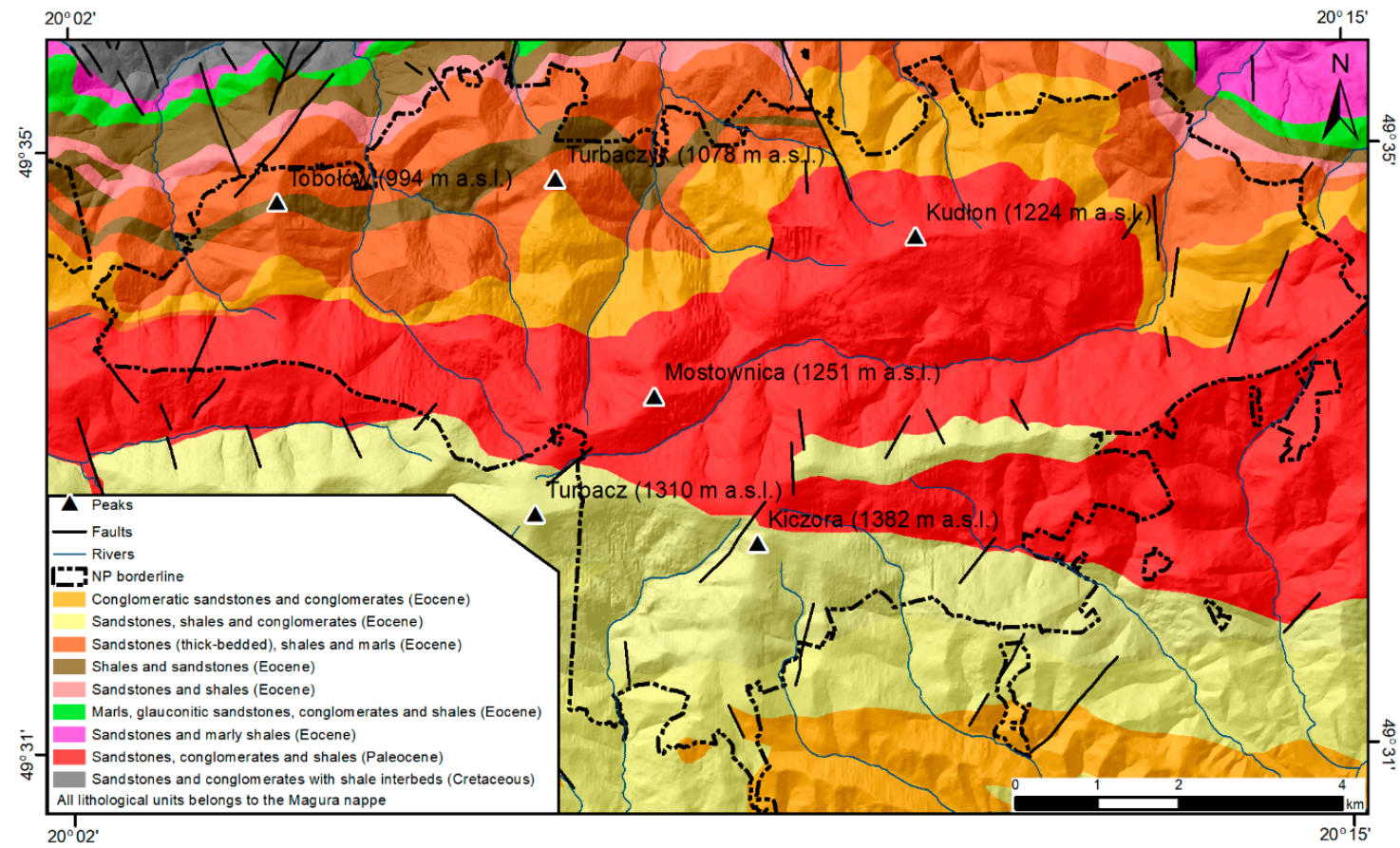

Figure 2. Gorczański National Park geological map. Source: [72].

\subsection{Geotourist Values of the Gorce Mts}

On the basis of the description of geological scientific values of Gorczański National Park and its surroundings, as suggested by many authors [72,73], the geotourist assets of the indicated area can be divided into three main groups, i.e., tors, mineral and thermal waters, and rock exposures (both natural and artificial).

The tors, most common on the ridges or in the upper parts of the slopes, are extremely varied in terms of shape and size. They consist of thick-bedded sandstones and thin conglomerates. The genesis of tors, either single or in groups, often with accompanying chasms and caves, is associated with several types of natural processes, i.e., with landslide movements, weathering, erosion, and denudation. The northern slopes of the Kudłon chain are particularly rich in tors, with the most famous attraction being Kudłoński Baca. Zbójecka Jama by the Jaworzyna Kamienicka is considered to be the largest cave in the Gorce Mts. Pucułowski Stawek by the Wysznia glade, an example of a pond formed in a recess of a landslide niche, is an interesting geotourist asset.

The second group of geotourist values of the Gorce Mts. are mineral and thermal waters. Rabka and Szczawa are two health resorts proud of their mineral waters. Rabka (Figure 1) is known for its salt waters ([72] after [74]), including sodium chloride, bromide, iodide, and barium waters. Thermal water was found in deep drillings in Poręba Wielka and Rabka ([72] after [75]).

The rock exposures (both natural and artificial, e.g., quarries) are the third main type of Gorce Mts. assets significant from the point of view of geotourism. A very good degree of flysch rocks exposure, often in a continuous form, occurring especially in the northern part of the chain, mainly in riverbeds and at the banks of rivers and streams, is a distinctive element of the Gorce Mts.

\subsection{Other Natural Sightseeing Values (Figure 3)}

Sightseeing values important from the point of view of geotourism also include scenic viewpoints, as indicated in the literature. It should be stressed that it is not so much the place that is important here as the panorama that can be admired. Thus, it is a point value in the physical sense, but its essence is a fragment of the landscape which can be appreciated. It is a very significant value, especially 
for lovers of inanimate nature, who can contemplate and learn about the effects of geological and geomorphological processes on the macroscale.

A total of 24 scenic viewpoints were set up in the park. Their spatial distribution is shown in Figure 3. They are evenly arranged, with a slight concentration in the southern part, so that the tourist visiting the park has a full overview of the most attractive panoramas offered by the park.

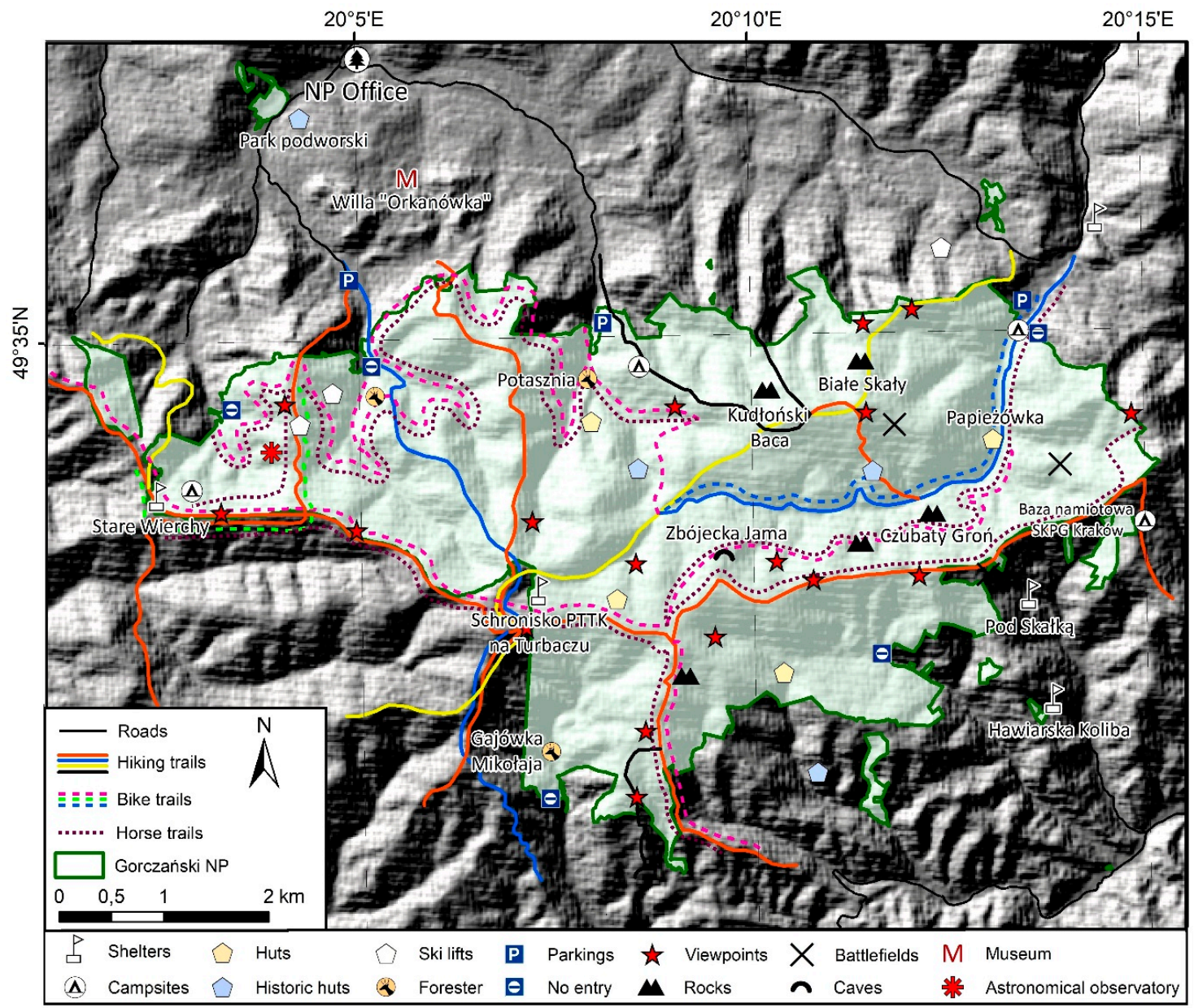

Figure 3. Selected natural and cultural values and tourist infrastructure of Gorczański National Park.

\subsection{Accompanying Infrastructure}

The accompanying infrastructure includes all facilities, both tourist and paratourist, which facilitate or enable tourists to practise specific forms of tourism. In the case of protected areas, these are usually selected forms of active tourism and cognitive tourism. In this group, geotourism plays an increasingly important role year after year. Among the devices that are present in the tourist space of the park, there are resources important for practising educational tourism. The entire teaching and administrative base is listed in Table 1. 
Table 1. Facilities of the accompanying base of Gorczański National Park for the needs of educational tourism.

\begin{tabular}{|c|c|}
\hline Facility & Tourist Function \\
\hline Management building & $\begin{array}{l}\text { Educational and conference facilities in Poreba Wielka, } \\
\text { conference and exhibition room for temporary exhibitions }\end{array}$ \\
\hline Gajówka Mikołaja & The educational and exhibition base in the Łopuszna valley \\
\hline Astronomical observatory & The highest located observatory in Poland, peak Suhory \\
\hline The education hall in the park hut in Hala Długa & $\begin{array}{l}\text { Educational activities, exhibition of the history of nature and } \\
\text { pastoral economy in the Gorce Mts. }\end{array}$ \\
\hline PTTK Mountain Tourism Culture Centre at Turbacz & $\begin{array}{c}\text { Museum of mountain tourism history in the Gorce Mts. } \\
\text { Surrounding area of Turbacz }\end{array}$ \\
\hline Papieżówka shelter & $\begin{array}{l}\text { The place of education classes, exhibitions; an exhibition about } \\
\text { John Paul II }\end{array}$ \\
\hline Shepherd's hut & Educational classes \\
\hline
\end{tabular}

Among other elements of the accompanying base, there are two ski lifts: the Tobołów cableway (a chairlift) and a surface lift at Koninki ski station. In addition, there are 10 forester's lodges in the park, three resting places (Obidowiec and camping fields Oberówka and Trusiówka), a roofed shelter on the route between Tobołczyk and Tobołów, and four car parks (Trusiówka, Potasznia, Koninki-Hucisko, and Parzygnatówka). Moreover, in the area of the park, sanitary facilities, information boards, and waste bins have been placed where tourist traffic is concentrated. There are also two GOPR (Mountain Rescue Service) buildings at Stare Wierchy and Tobołczyk.

\subsection{Hiking, Bike, and Horse Tourist Trails}

One of the elements of the accompanying base for transport accessibility within the region is tourist trails. There are hiking, bike, and horse trails (Figure 4). In the first group, there are 10 trails of varying degrees of difficulty, time to be devoted to its passage and qualities that are presented on the route. The time of passing, depending on the trail, is from one hour and a quarter to $7.5 \mathrm{~h}$. The thematic scope of the trails is diverse. The blue trail coincides with the Papal Trail, which imitates the course of the favourite routes of the later Pope John Paul II, who often visited the park. The yellow trail, five hours long, passes through 10 glades, where there are huts associated with the pastoral economy of the region. 


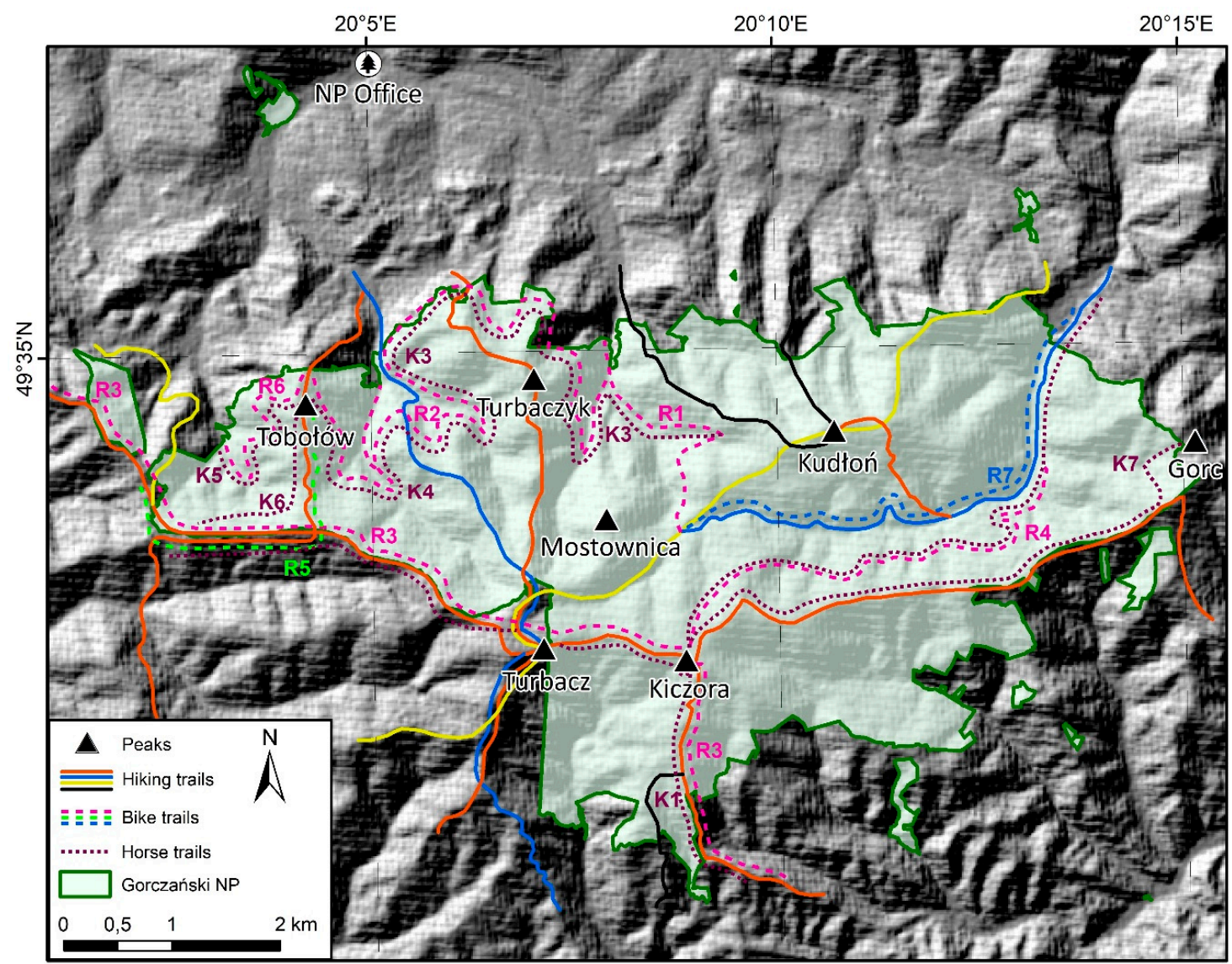

Figure 4. Hiking, bike, and horse trails in Gorczański National Park.

It is worth noting the black trail in the southern part of the park. The walk time is two hours and the theme is the value of the animated and inanimate nature of the park.

For those interested in geology and geomorphology, another black trail, in the northern part of the park, is important. The time of the trail is $4.5 \mathrm{~h}$. On the steep slopes, there are numerous exposures of Carpathian flysch with visible layers of shales and sandstones. There are also several rock outcrops.

Another important geotourism point is the blue trail from the Trusiówka glade through the Kamienica valley to the Borek pass in the eastern part of the park. It will take about $3 \mathrm{~h}$ to get there. On the route, we can observe exposures of Carpathian flysch with visible layers of shales, sandstones, and conglomerates. They are a result of water erosion. The effects of the destructive activity of mountain streams can be observed here.

This type of trails is the park's specialty. Their characteristic feature is their low level of difficulty. The main recipients of the offer are families with children.

In total, the trails in the park have $74 \mathrm{~km}$. Bike and horse trails are shorter. The total length of bike trails in the park is $53.5 \mathrm{~km}$. The average length of a trail is $7.6 \mathrm{~km}$, with the longest one-R3-being $11.3 \mathrm{~km}$, and the shortest one-R5-being $3.3 \mathrm{~km}$.

The six horse trails are $47.3 \mathrm{~km}$ long. The longest ones are $\mathrm{K} 1-11.3 \mathrm{~km}$ and $\mathrm{K} 2-11.4 \mathrm{~km}$. The shortest is K6-only $3.3 \mathrm{~km}$. It should be emphasized that almost $90 \%$ of tourists move around the park on foot.

\subsection{Didactic Routes}

The most important element, also exploited by geotourism, is thematic didactic routes, i.e., hiking trails marked out in a way to include as many objects important from the didactic point of view as possible. Significant components of this kind of routes are stopping points, here referred to as geotourist 
stops, which expose interesting geological and geomorphological assets. They are accompanied by information boards that present the assets and explain the associated phenomena and processes. There is a total of 10 didactic routes in the park (Figure 5). In almost every case, the leading theme is of an animated and inanimate nature. For two of them, the cultural heritage and history of the region are essential elements. The park authorities put emphasis on developing this offer, as education is one of their priority tasks.

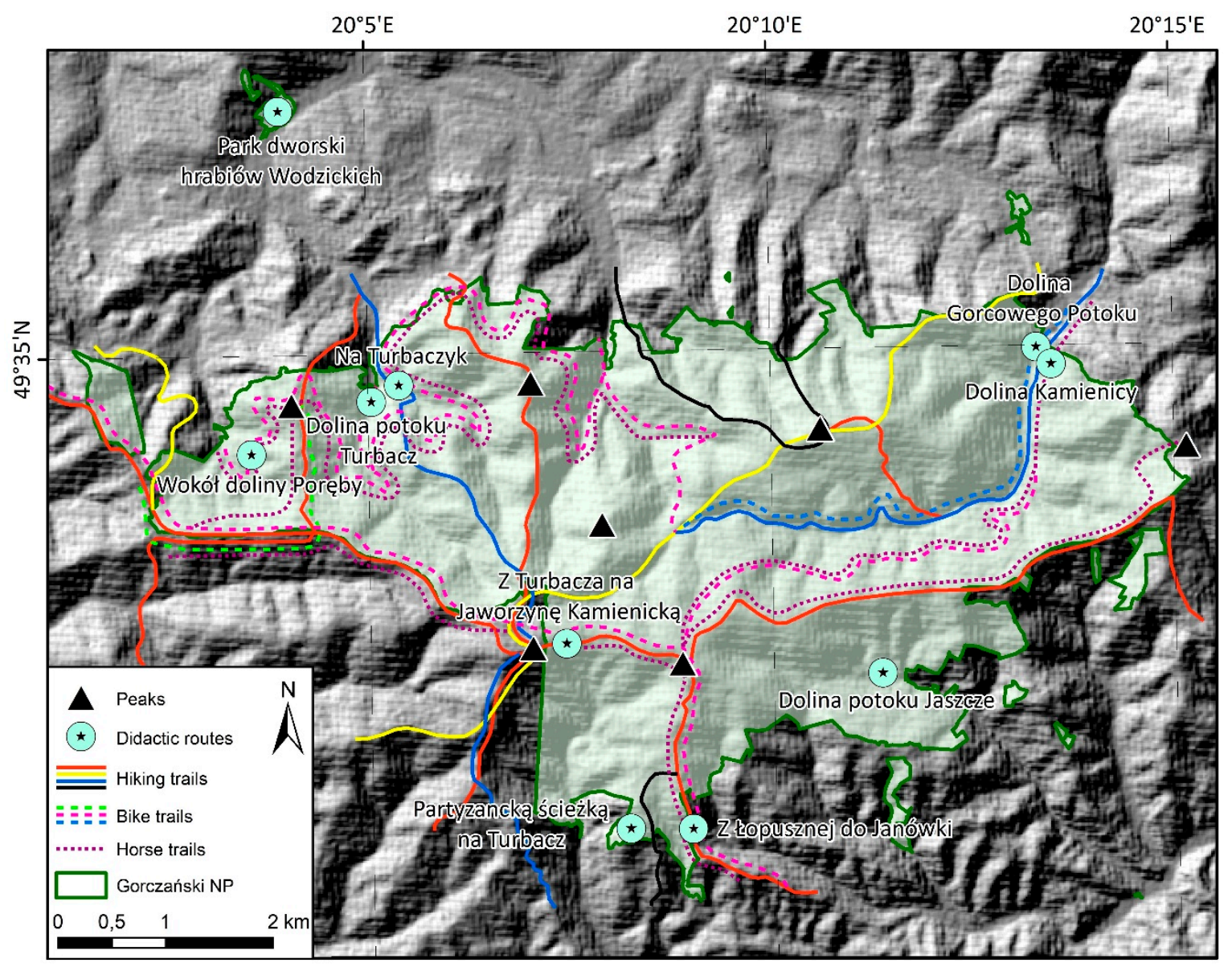

Figure 5. Didactic routes of Gorczański National Park.

Although the educational offer is varied, it is mostly devoted to issues that refer to the animated nature. Despite that, important elements related to the geology and geomorphology of the park are not neglected. Only in the case of two routes, no inanimate nature didactic stop was proposed. In the case of the other routes, there are usually one or two stops, with over 11 learning stops on average (Table 2). 
Table 2. Geotourist elements of the didactic routes in Gorczański National Park.

\begin{tabular}{cc}
\hline Route & Geotourist Stop \\
\hline Dolina Gorcowego Potoku & Geomorphology of mountain brooks \\
\hline Dolina Kamienicy & Geological exposure, rock \\
\hline Dolina potoku Jaszcze & $\begin{array}{c}\text { Geological structure, soil, geomorphology of the } \\
\text { mountain brook }\end{array}$ \\
\hline Dolina potoku Turbacz & Geological structure: tectonic window \\
\hline Na Turbaczyk & The rock outcrop underneath Wysznia \\
\hline Park dworski hrabiów Wodzickich and Chabówka & Torfowisko wysokie. Trzy Kopce \\
\hline Wokół doliny Poręby & Mountain brook \\
\hline Z Łopusznej na Jankówki &
\end{tabular}

It should be emphasized that each of the didactic routes is equipped with a unified system of visual information and small tourist infrastructure of the park, stop posts, signposts and information boards. As intended by the creator, didactic routes are a tourist product allowing visitors to reach the most interesting places in the park.

\subsection{Tourist Traffic in Gorczański National Park}

In the current decade, we can speak of an increase in tourist traffic in Gorczański National Park that moved from 60,000 visitors in 2010 up to 90,000 visitors in 2017 (Figure 6).

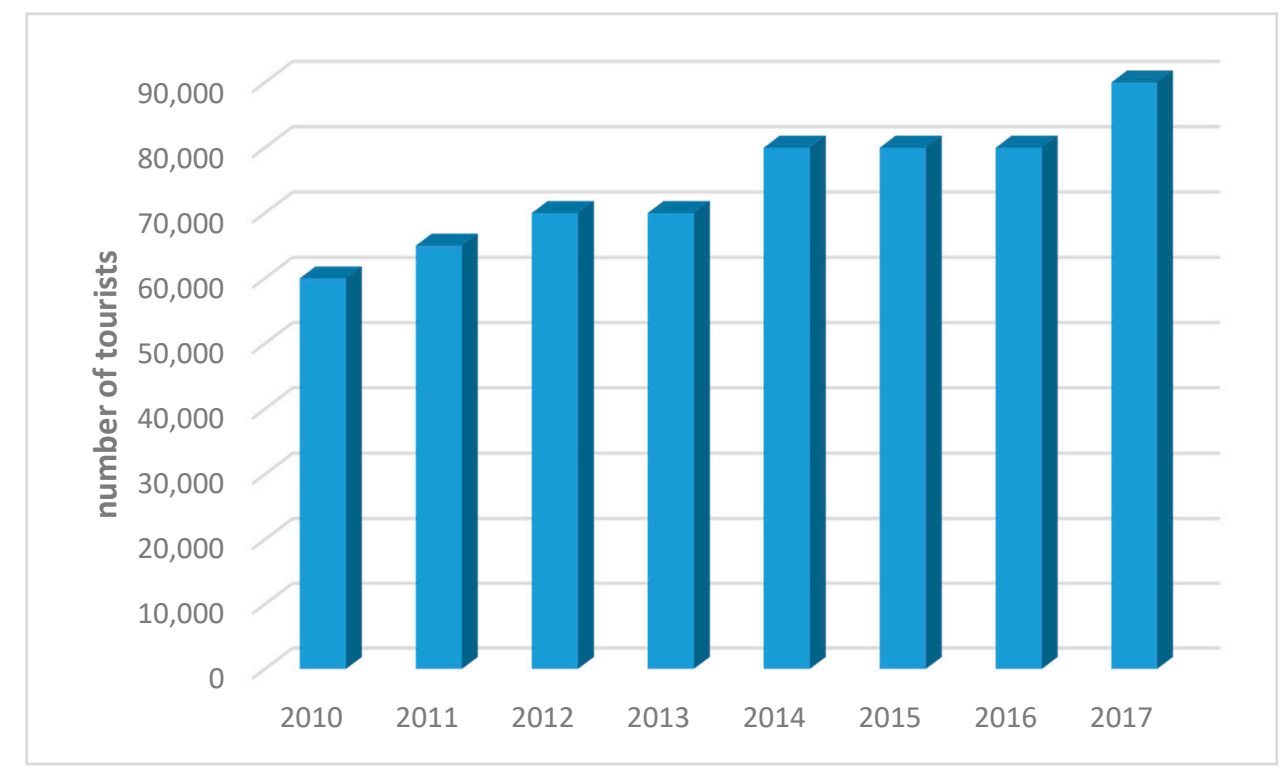

Figure 6. Number of tourists in Gorczański National Park in years 2010-2017. Source: [76-83].

Less than $170 \mathrm{~km}$ of trails are traversed by almost 100,000 people [83], which gives 13 people per hectare regarding park area and 533 people per kilometre regarding trails. This puts the park in the 15th place overall when taking into account the number of tourists per kilometre of a trail and the number of tourists per hectare of the park area.

The moderate tourist load of the park paradoxically increases its tourist attractiveness. A relatively small number of tourists (in 2017, the park was the 16th park in the ranking of the volume of tourist 
traffic in the country, with the number of tourists 42 times lower than the record-breaking Tatrzański National Park) significantly increases the comfort of a tourist holiday, regardless of its character as active or passive. This is also important because of the quality of the park's tourist attractions. With a few exceptions, national parks in Poland look for a sustainable approach between the duty of nature conservation, including inanimate nature, and opening up to the growing tourist traffic and the associated risks every year.

Each national park, also in Poland, is obliged to prepare and consequently implement a nature conservation plan in its area. The same is true for Gorczański National Park, which also implements a nature conservation plan, designed in 2018. The first step is to determine the type and nature of threats to inanimate nature resulting from human activity in the park area, including activities related to the growing tourist traffic every year.

\subsection{Threats to the Inanimate Nature Resulting from the Tourist Traffic in Gorczański National Park}

The size of tourist traffic in valuable natural areas affects their quality and conservation status. This is a kind of paradox - the more valuable and attractive a natural area is in the opinion of tourists, the greater tourist traffic is observed, which translates into a greater threat to the balance in nature in the protected area. In the literature, a whole set of threats is repeatedly pointed out, of which managers in the protected area are aware. Noise, pollution, or anthropopressure are indicated among them [84]. Partyka [85] draws attention to the excessive attendance of visitors and the thickening of tourist trails in the most popular places, trampling wild paths, damaging root systems, trees, destroying vegetation and soil, noise, disturbing animals, causing fires, littering, changes in the landscape and microclimate, synanthropization of flora and fauna, and changes in the structure of biocenoses. Similarly, Baraniec [86] points to anthropogenic denudation, destruction in vegetation, or littering, which diminishes the aesthetic values of the park and has a negative impact on the animal world. Wieniawska [87] emphasizes the threat related to the development of infrastructure, especially skiing. Hiking, most popular in the summer in mountainous areas, destroys nature on tourist trails. Tourists can destroy the vegetation cover, create shortcuts between paths, destroy the surface within the paths, cause loose material movement, etc. [88].

The overwhelming majority of literature on the subject points to the threats of animated nature, assuming that elements of inanimate nature, as more resistant to the environment, are less threatened $[86,88]$. It is worth confronting this position with the opinion of institutions that are responsible for the management of protected areas, in this case, national parks.

In accordance with the requirements of the Act on Nature Conservation [89], the threats to the animated and inanimate nature in Gorczański National Park are defined in the conservation plan for the park, developed by the park management. In addition to the identification of threats, ways of eliminating or significantly reducing them are also indicated. The draft plan of 2018 [90] identifies four groups of threats:

- $\quad$ existing internal threats;

- potential internal threats;

- $\quad$ existing external threats;

- $\quad$ potential external threats.

The first group includes 17 types of risks. Erosion of internal roads, routes, and trails as a result of tourist traffic and log-rolling is the most important for inanimate nature in the light of the analysed document. Among the most endangered resources, the authors of the document include inanimate nature, namely soil and bedrock. The way to remedy the problem is, among other things, renovation of roads, trails, and routes, as well as educating tourists and local residents on how to move around the park, combined with tourist traffic control. Other problems are vandalism (littering the ground, burning bonfires, devastation of huts, etc.), forest damage, and poaching. Among the endangered park resources, there are forest ecosystems, selected animal species, cultural assets, and also inanimate 
nature. One way to prevent potential harm is to educate the local community and tourists accordingly. Another internal threat is tourist traffic, gathering. Inanimate nature is less at risk, and appropriate channelling of this traffic (correction of trails in order to keep the tourists away from the immediate vicinity of assets) combined with education of the traffic participants is indicated as a means to achieve the goal. The last-named threat to inanimate nature, and especially to soils and rock exposures, is inappropriate repairs of internal roads (slope and valley roads), including bridges, culverts, and tourist infrastructure. The answer to the problem is to carry out anti-erosion protection, conduct road repairs with consultation with hydrologists and geomorphologists, and reduce the work in the vicinity of the stream beds to the necessary minimum.

Among the internal threats that are potentially dangerous to inanimate nature are illegal climbing onto rock outcrops, unauthorized cave penetration, and collecting rocks and minerals. As a remedy, it is suggested that the ban on both activities should be maintained, reinforced by an appropriate educational campaign. In the third group, the most important threat to inanimate nature is the loss of ecological connectivity of the park with the neighbouring areas through such activities as development of banks and regulation of water courses, and development of sports and recreation infrastructure. The way to remedy the problem is to monitor investment plans in the buffer zone of the park and to cooperate with local authorities, organizations, and tourist businesses on solutions limiting the unfavourable influence of sport and tourism on nature. No external potential threats are seen.

Thanks to proper management, the natural resources of Gorczański National Park, including geotourist ones, can be an important factor in attracting tourist traffic. The park authorities, trying to protect these resources in accordance with legal requirements, also by ensuring their proper accessibility, have an influence on how tourists assess the attractiveness of the park. It is important to see how the tourist potential of Gorczański National Park is evaluated by tourists who visit this mountain range as part of their weekend tourism and what the function is of the geotourist potential in this group of visitors.

\section{Materials and Methods}

The study on the tourist attractiveness of the park as an area conserving and presenting valuable natural resources, including those of inanimate nature, was carried out among 252 tourists visiting the park. The survey was conducted in three rounds in the 2016 and 2017 tourist season. In 2016, the survey was held during a so-called long weekend, when a weekend is accompanied by additional days off due to national holidays, as it was in the period of 29 April-3 May 2016; 104 questionnaires were then collected, 5 of which were rejected. At the turn of September and October (30 September-2 October) of 2016, despite good weather conditions, only 39 questionnaires were collected, with only 1 rejected. In 2017, tourists were surveyed in mid-April (12-14 April 2017), when the tourist season practically begins, traditionally marked by the appearance of the park's characteristic crocuses. At that time, 101 questionnaires were collected, while 2 were filled in incorrectly. In total, 252 questionnaires were collected (8 were rejected), so the survey was based on 244 correctly filled-in questionnaires. The main assumption was to determine the attractiveness of Gorczański National Park as a potentially important tourist destination for weekend tourism. This is due to the specific location of the park, about 70 $\mathrm{km}$ from the centre of Poland's second largest urban agglomeration, Kraków. It can therefore be assumed that because of the distance and relatively good communication-with national road No. 7, S7 express road, and voivodship road 986-the park is an attractive destination for tourists who wish to actively spend their weekend free time. That is why it was decided to conduct the research in a period traditionally referred to as a long weekend in Poland, when there is an accumulation of holidays: 1 and 3 May are public holidays. In 2016, it was Sunday and Tuesday. Practically then, the weekend tourists had time off from Friday evening 29 April 2016. It is already the full weekend season in the park. The next two research periods were the beginning of the park season, which coincided with the Easter period of 2017, and the end of the season-the weekend at the turn of September and October-when the weekend tourists can still count on good weather, as it was in 2017. 
The questionnaire, as in other studies on the tourist attractiveness of protected areas, consisted of three main parts. The first one referred to the characteristics of the group of respondents and included standard questions relating to gender, age, education, and place of residence. It resulted in establishing a socio-demographic profile of tourists visiting Gorczański National Park. Then, the purpose of the visit was determined. In addition to the three most popular objectives proposed in the question, the participants could also indicate another objective if they did not declare any of those contained in the question. The next part focused on the evaluation of the park's tourist offer, which is one of the important ways of presenting natural resources, including geotourist ones, of the protected area. The third, final part was devoted to the general assessment of the tourist attractiveness of Gorczański National Park.

The group of the surveyed respondents comprised all the tourists who appeared on the trail, at the place where the survey was conducted, at the indicated time. The difficulty in determining a representative study sample was highlighted by many authors $[10,91,92]$. Therefore, we adopted the principle of surveying all tourists who appeared in the park at the time specified in the survey. We also decided to analyse all the questionnaires collected during holiday periods crucial for weekend tourism. The sample size does not differ considerably from that examined during similar studies devoted to the analysis of tourist traffic preferences and assessments of tourists visiting protected areas [10,93-97].

Answers to the survey questions were obtained with the face-to-face interview technique, which ensures a high level of correct replies [94].

The questions were designed carefully, to avoid potential inaccuracies and reduce the number of ambiguous answers. Some of them were closed questions, where the respondent could choose, depending on the question, one or two answers-as in the case of the question about the most attractive of the proposed values located on the tourist trails in the park. In the next group of questions, a 5-point Likert scale was applied. They concerned the respondents' opinion on particular trail elements. The tourists indicated their assessment ranging from "I strongly disagree" to "I strongly agree". The question summarizing the third part of the survey was an open one, so that the respondents could freely express their opinion on the attractiveness of the visited park.

\section{Results and Discussion}

\subsection{The Tourist Attractiveness of Gorczański National Park from the Opinion of Tourists}

One of the main objectives to establish national parks was nature conservation, intended to interact with the sustainable use of their natural resources for education, research, and recreation $[98,99]$. Recreational use of national parks is increasing all over the world [47,100-102]. It is therefore not surprising that the issue of tourism in protected areas, including parks, is an important research subject also in the context of tourist traffic $[11,103,104]$. The perception of protected areas attractiveness has been explored in many studies [8,92,105-108]. This is all the more significant as the vast majority of environmentally attractive areas are exposed to pressure from tourist traffic $[47,109,110]$, which also impacts on the operation of national parks.

First, it is worth it to present a profile of the tourists visiting Gorczański National Park as it emerges from the information provided by the respondents themselves.

\subsubsection{Tourist Profile}

Numerous publications list a number of different factors influencing tourism in protected areas. They point at the level of education, place of residence $[8,108]$, satisfaction with the products or services offered [8,92], as well as specific values. The choice of destination is influenced by socio-demographic variables such as age, gender, place of residence, and level of education $[21,24,111]$, as well as other aspects related to recreation [21,112-116].

This applies especially to tourists visiting protected areas [117,118]. Relationships between the examined factors are also indicated. Investigators sometimes demonstrate the correlation between 
the respondents' age and landscape perception: younger people turn out more sensitive to this element [113]. Other studies emphasize that young and well-educated tourists usually present more ecological attitudes [119-123]. Similar results were obtained in our study on the profile of tourists visiting Gorczański National Park.

The majority of the surveyed visitors to Gorczański National Park were young people aged 15-45 years. Children and visitors over 60 years of age were the least numerous (Figure 7).

Consequently, the park, located relatively close to a large Polish urban agglomeration (Kraków), is an important weekend destination for people of an age that favours an active form of recreation, and the distribution in the three age groups between 16 and 60 was relatively even (Figure 7). The attractiveness of a park as a place of active recreation is also commented on in other studies, which, besides parks' attractiveness resulting from accumulation of valuable natural assets, imply their perfect suitability to practise numerous activities [124,125].

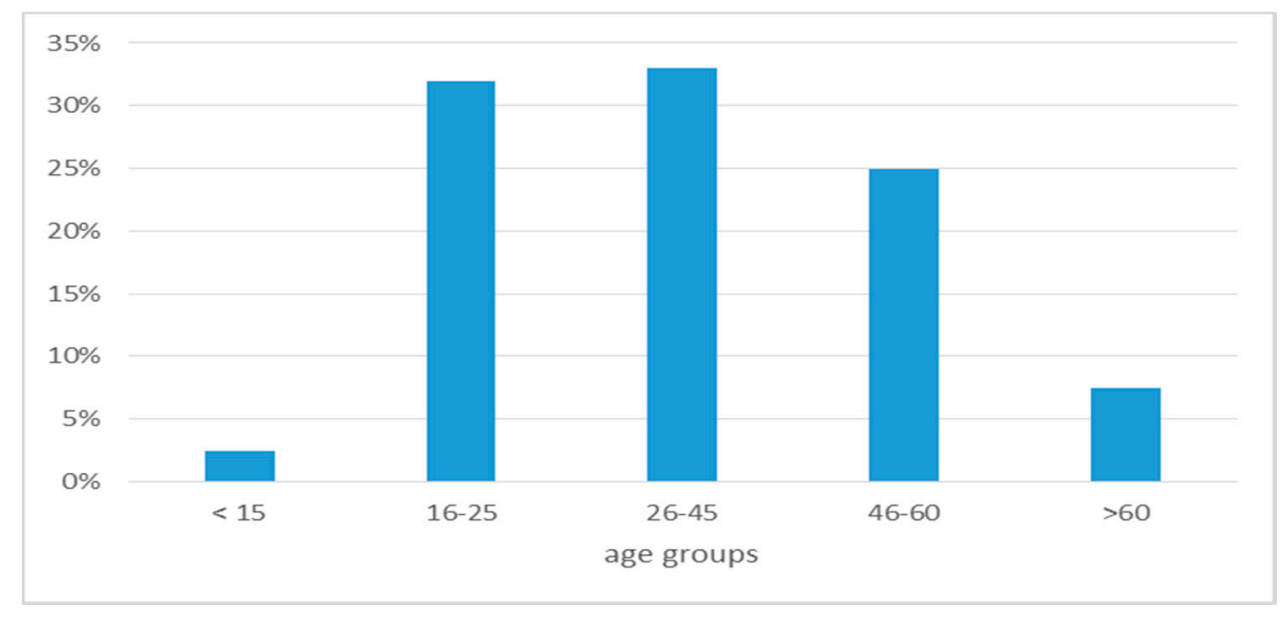

Figure 7. Age structure of respondents.

As far as gender is concerned, the group of women was slightly more populous. Women prevailed in groups up to 25 years of age and in retirement age, preferring the walking trails offer. In the case of men, the park was most popular for weekends in the age groups of 26-45 and 46-60 years. Women show greater interest in understanding nature conservation $[23,117]$ than the surveyed men visiting protected areas. Thus, the potentially greater representation of women among the visitors to Gorczański National Park may translate into a greater understanding of the activities aimed at protecting the park resources, also the ones that may to some extent limit the resources availability to visitors.

It is worth noting that the vast majority of tourists active in the park area were people with higher education. These were 137 people, or $56 \%$ of the surveyed population. Every third person had secondary education. Only $11.5 \%$ declared vocational education, while only $2.5 \%$ had primary education-six girls under 15 years of age. In the group of people with higher and secondary education, women prevailed (55\%), while men more often had vocational education (60\%) (Figure 8 ). 


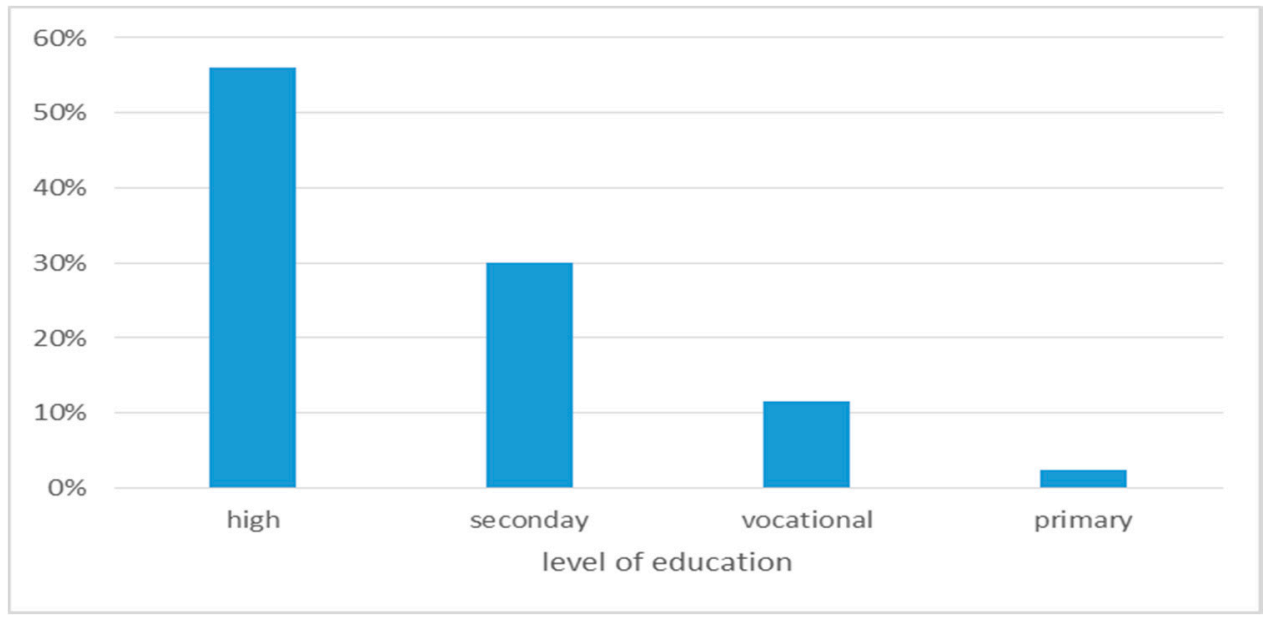

Figure 8. Education structure of respondents.

The results relating to the age or education of visitors to protected areas are in line with a broader trend observed in many national parks with reference to demographic factors $[117,118]$. Some investigators imply a higher sensitivity to landscape assets among younger tourists [113]; others observe more ecological attitudes in young and well-educated tourists [23,119-123]. Taking these relationships into account and analysing the data from Gorczański National Park, one can risk a thesis that with such a group of tourists, all actions aimed at the sustainable, pro-protective development of the region will be easier, as they will encounter a higher understanding among visitors.

\subsubsection{Region of Origin of the Respondents}

In the context of the character of weekend tourist trips, the spatial distribution of places from where tourists came to visit Gorczański National Park appears interesting (Figure 9). Not surprisingly, the biggest share was held by people from the Lesser Poland province-the region where the park is located. Almost every third person came from this province (mainly from Kraków and smaller cities in the vicinity). Every fifth tourist arrived from the Silesia province, bordering on the Lesser Poland province. The distribution of the tourists' origin combined with their count indicates that the park, from the tourist's point of view, is a destination of regional importance.

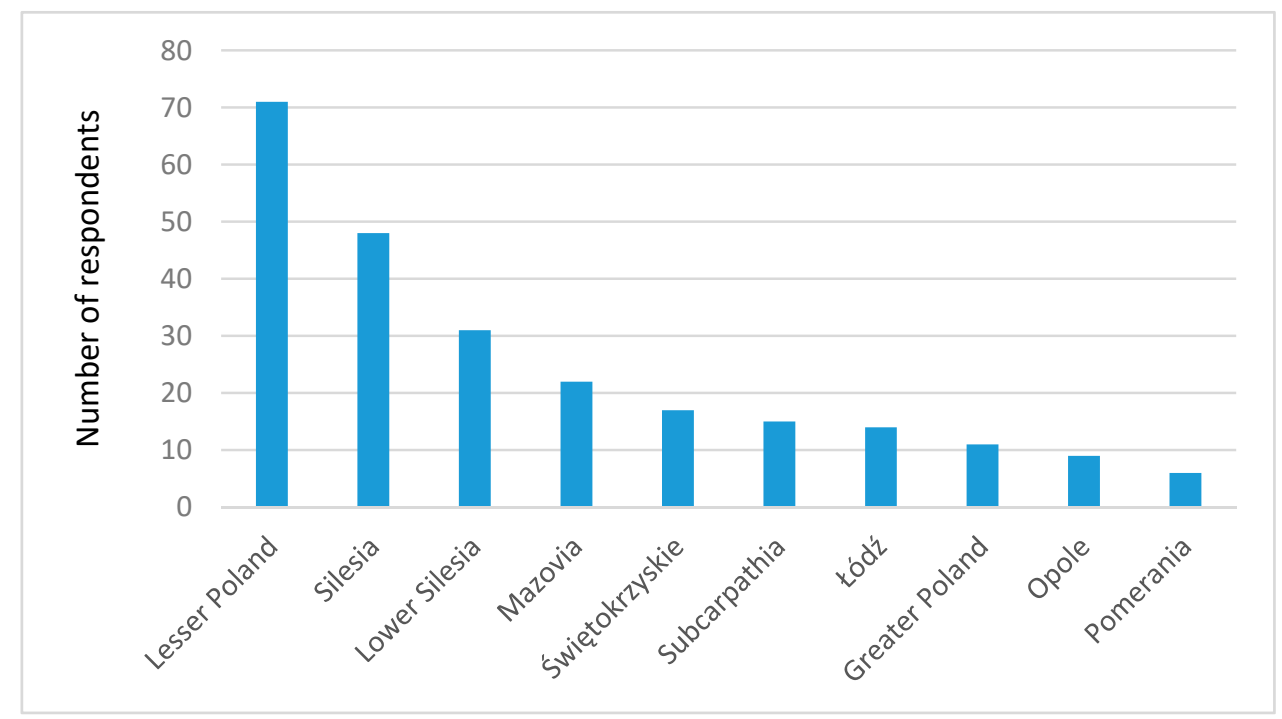

Figure 9. Provinces of origin of respondents visiting Gorczański National Park. 
The park attractiveness in the region in which it is located seems to be a common issue for many protected areas studied and described in the literature. Peripheral location together with the attractiveness of the natural values themselves, including geotourist ones, is regarded as an important factor inviting tourist traffic [126]. The relatively close location of the park also increases its attractiveness for weekend tourists and same-day visitors [125].

\subsubsection{Purpose of a Visit to Gorczański National Park}

Motivations driving tourists to visit areas of natural attractiveness are an important subject of research [127-132]. Butler and Boyd [133] or McCool [134] are not the only ones to stress that the knowledge of tourists' preferences and the purpose of their visits is the foundation to create the tourist offer in protected areas. Wide knowledge of the opinions and preferences of tourists visiting protected areas translates significantly into efficient and coherent management of resources in these areas $[135,136]$. The research results that refer to the goals and motivations of tourists visiting Gorczański National Park seem interesting.

When asked about the purpose of the trip (Figure 10), the tourists indicated four main answers: a trip to the mountains, recreation, visiting family or friends, a different aim. For $66 \%$ of those surveyed, Gorczański National Park was the main tourist destination, while for the remaining $34 \%$ it was a secondary one.

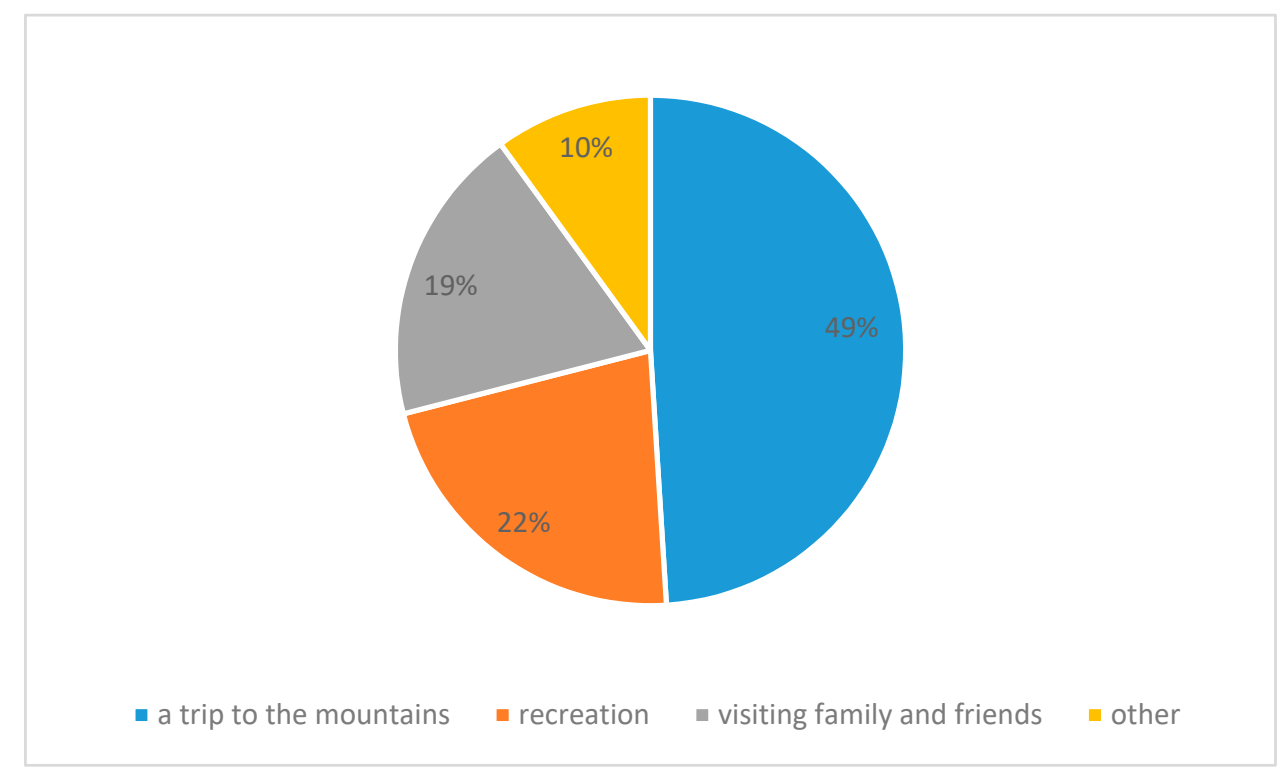

Figure 10. Purpose of a visit to Gorczański National Park.

Although many reasons influence tourists' decisions to visit a protected area, some common points can be identified with other areas described in the literature. Tourists visiting protected areas, including national parks, arrive there to experience positive emotions [137-139]. When analysing the experience of a tourist visiting a park in more detail, one can indicate the categories of tourist experience proposed by Pine and Gilmore [140]. There is an "education" category among them, which includes tourists looking for new experiences by learning based on active participation [141]. This is perfectly suited by the linear tourist product, which will be mentioned below: didactic routes. In the case of protected areas, the "escapism" category is especially significant, referring to the tourist's escape from his daily routine combined with an attempt to learn a new self [130,142-145]. These experiences are usually associated with an active form of space exploration, such as cycling, horse-riding, etc., which is also emphasized by Gorczański National Park visitors. Another important fact is worth 
noting: The experience of positive memories translates into a positive attitude of the tourist towards the visited region $[137,146]$. This also refers to protected areas.

The specificity of weekend tourism in Gorczański National Park is rather an individual formula of the trip. This is also true for research on a group of tourists visiting the park. Almost 9 out of 10 people $(89 \%)$ came here alone $(20 \%)$ or accompanied by their close family or friends $(69 \%)$. This is a feature common to national parks visited by weekend tourists [25]. It is important to highlight the declarations of individual visitors, who stressed that they visited the park at any time of year.

\subsubsection{Evaluation of Trails and Educational Offer of Gorczański National Park}

Tourism should not be assumed to oppose nature conservation. It is worth emphasizing that the broadly understood development of tourism may translate into proper implementation of the area protection goals, including a very important educational goal [147,148].

Research on tourist traffic also affects the management of natural resources in protected areas, including national parks. The knowledge of tourists' preferences, motivations, and behaviours may influence the activities of the managing authorities when creating marketing strategies and specific tourist products offered in protected areas $[130,145,149,150]$. Examples include the didactic routes of Gorczański National Park.

A well-developed tourist product translates into increased attractiveness of the national park, especially among tourists interested in exploring the natural resources of the region [27,151].

The assessment is all the more important because it shows the natural resources in the park, including geotourist ones, as perceived by the surveyed tourists. The majority of tourists had no objections to the accessibility, safety, or comfort of the trails and presented a positive attitude toward the difficulty of the park trails, finding them rather easy. The tourists were not so unanimous in assessing the cleanliness of the trails: The majority thought that they were clean or rather clean, but almost every third tourist considered them not clean (Figure 11).

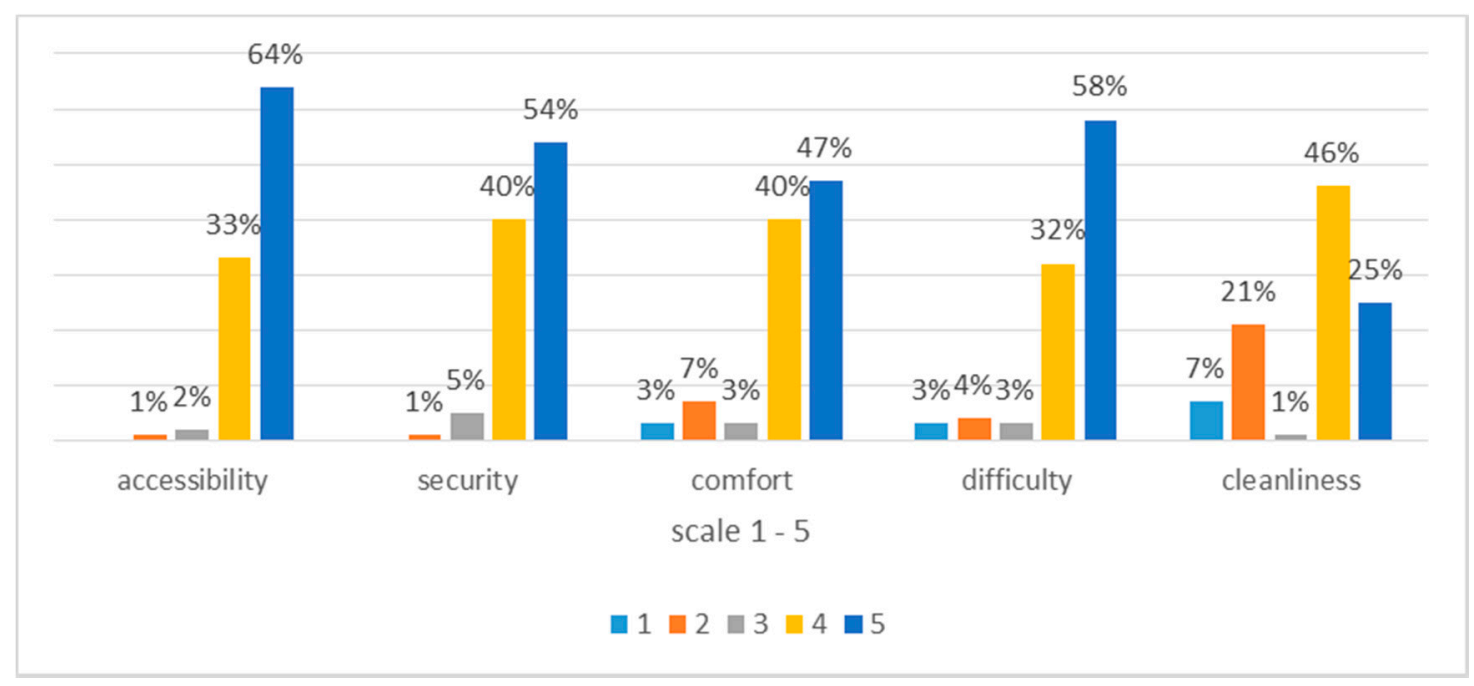

Figure 11. Evaluation of trails in Gorczański National Park.

The respondents were also asked about the attractiveness of particular trail elements. During the preliminary research, the most popular set of elements was determined. These were views/panoramas; water facilities, including streams and ponds; rocks and other geological features; as well as glades with elements of pastoral culture, i.e., huts. Tourists had the opportunity to indicate two of the proposed items that they considered the most attractive. A total of 352 responses were collected out of the possible 488 . The panoramas received the biggest number of indications: $54 \%$. The landscape of the protected area with its surroundings was important for tourists. It is not much of a surprise. Many 
publications point to the decisive role of landscape in the tourism of protected areas [152]. It is therefore not astonishing that knowledge of its reception is important for the proper management of this type of resources and plans for their maintenance and promotion [153]. The quality of the landscape is one of the most important assets of areas of high natural value [154]. This is important for many reasons. The landscape attractiveness can translate into the quality-of-life of the local community and income for the region as it contributes to the quality of the tourist experience [155]. It is important in this context to propose a linear product that would integrate the attractive points of the area visited [156]. One of the ideas are all trails based on a specific type of value, as in the case of didactic routes, discussed below.

Thanks to its location, Gorczański National Park offers one of the most beautiful panoramas, especially the view of the Tatra Mountains - the highest mountain range in Poland. Ranked next in terms of the number of indications were elements of landscape of inanimate nature connected with local culture: glades with huts, which are a hallmark of the park. The third place was taken by other elements of inanimate nature, directly related to the geotourist offer of the park-rocks and rock clusters (Figure 12). The importance of the park's geotourist resources for visitors is worth emphasizing at this point. Although the main protected element in the park is animated nature, the geotourist qualities that constitute inanimate nature resources are considered to be the most attractive to visitors.

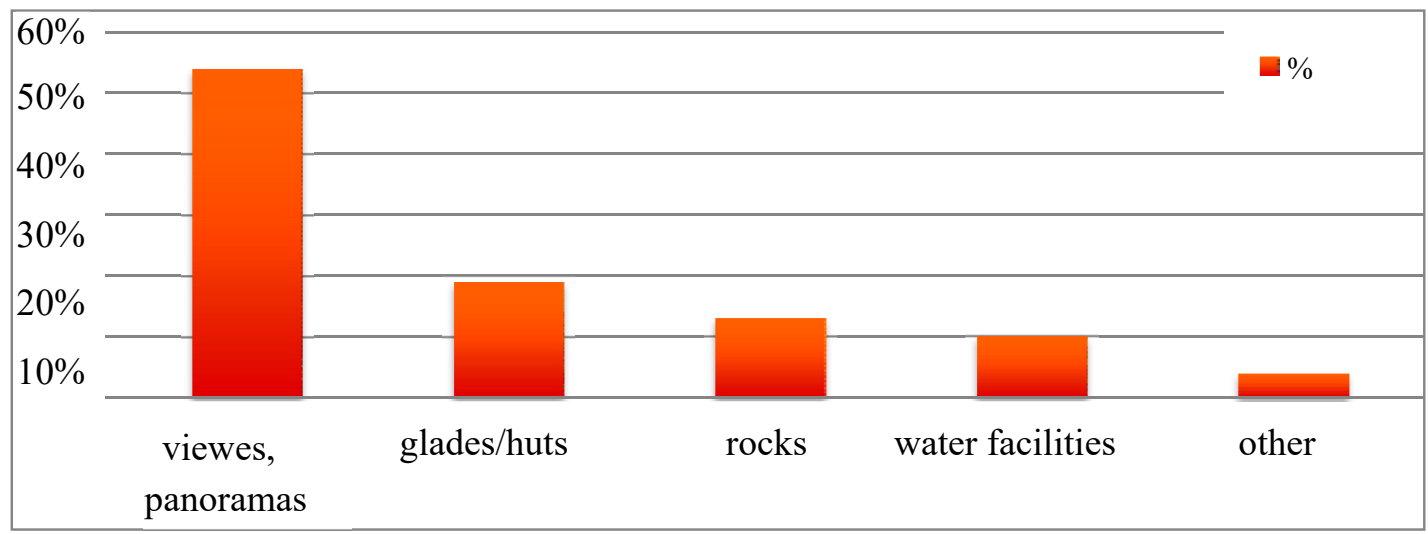

Figure 12. The most attractive elements of trails of Gorczański National Park.

\subsubsection{Didactic Routes in the Opinion of Tourists}

An important tool for the proper use of a national park values, including geotourist ones, is interpretation. It not only has an educational function, but also supports the protection and maintenance of park resources. After all, it is an important tool for managing the resources. A well applied interpretation may contribute to reducing the negative impact of tourist traffic on the park resources. One of the important channels of interpretation are markings, educational centres, or, which is important in the case of the examined Gorczański National Park, trails, as well as didactic routes [157]. Such an interpretation of a linear nature may help properly distribute the tourist traffic in the park area. It is also worth noting that interpretation facilitates tourists' involvement in the active exploration of the area [158]. Thanks to interpretation, apart from the very knowledge of resources, an understanding arises of the need for nature protection and appropriate behaviour in the natural environment. It also increases the level of tourist satisfaction with visiting the particular region and its resources. The same is true for Gorczański National Park. The type of interpretation that lies behind the didactic routes has been very positively evaluated.

A separate part of the survey was devoted to the evaluation of the educational offer of the park, with geotourist topics prominently present. The offer of didactic routes is the most popular form of education. When asked if they knew about it, the majority of the respondents gave negative answers, despite the park management efforts to promote this kind of education. The surveyed weekend tourists may not be familiar with the offer because it is addressed primarily to organized school groups at different levels of education. Those who knew the educational offer were most frequently familiar 
with the route Park dworski hrabiów Wodzickich-Chabówka, where one of the 16 stops is dedicated to geotourism (geological structure: tectonic window), then Dolina potoku Turbacz (two geotourist stops), Wokół doliny Poręby, and Dolina Gorcowego Potoku (one geotourist stop).

The majority of people using the offer of the didactic routes had a positive attitude towards the infrastructure accompanying the routes and were satisfied with the number of information boards and their distribution within the park (Figure 13).

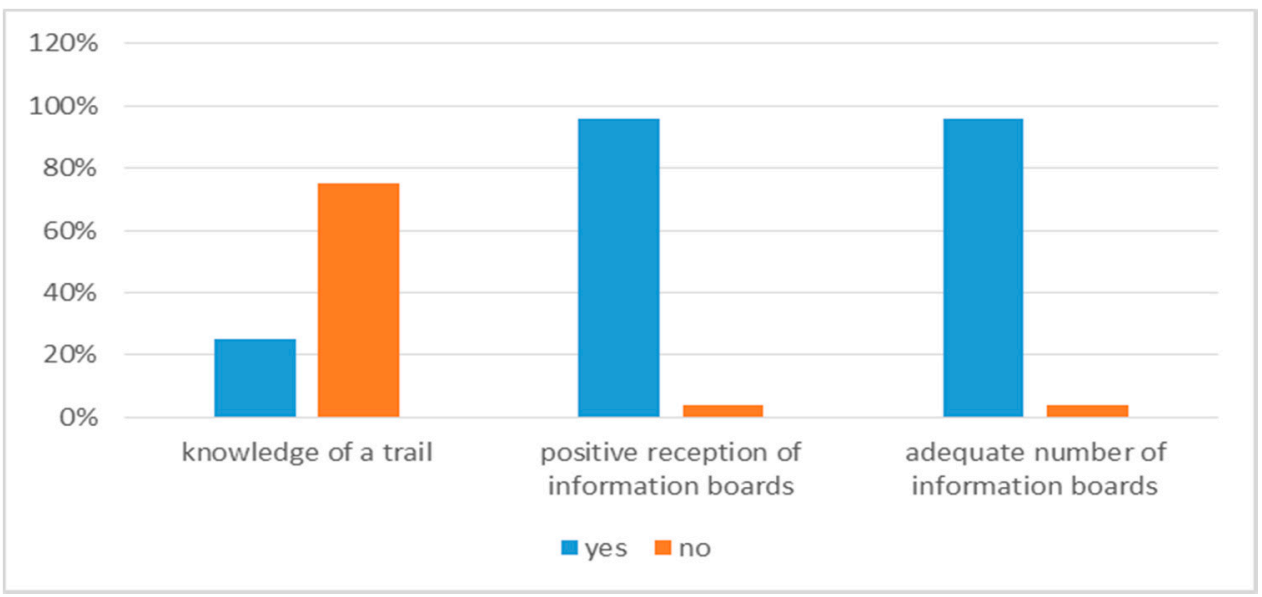

Figure 13. Didactic routes of Gorczański National Park in the opinion of tourists.

\subsubsection{General Assessment of Gorczański National Park}

Finally, it is worthwhile to look at the problem of tourist satisfaction, which affects the overall assessment of the resources used by the tourist. This is an important issue: customer's satisfaction, its level, as well as knowledge about it are important for tourism management $[159,160]$. This applies, for example, to the loyalty of the tourist to the destination or the income derived from tourism in the region [161]. After all, it depends on the level of satisfaction whether a given region or product will be recommended to others [160]. Therefore, tourists' satisfaction related to the visited region is crucial for the tourism industry and its economic development [162,163]. The satisfaction level is a derivative of the level of the region tourist development [164]. This is important for protected areas, increasingly dependent on the development of sustainable tourism. A high level of satisfaction translates into a higher probability that the tourist will be more likely to return to a region that brings positive associations [165]. It is interesting to look at the evaluation of Gorczański National Park in this context.

The vast majority of respondents confirmed the validity of the authorities' decision to create a national park and the need for the conservation of animated and inanimate nature in the Gorce Mts., which would emphasize its uniqueness at the same time. The general impression about the tourist attractiveness of the park was very positive among the respondents (Figure 14). 


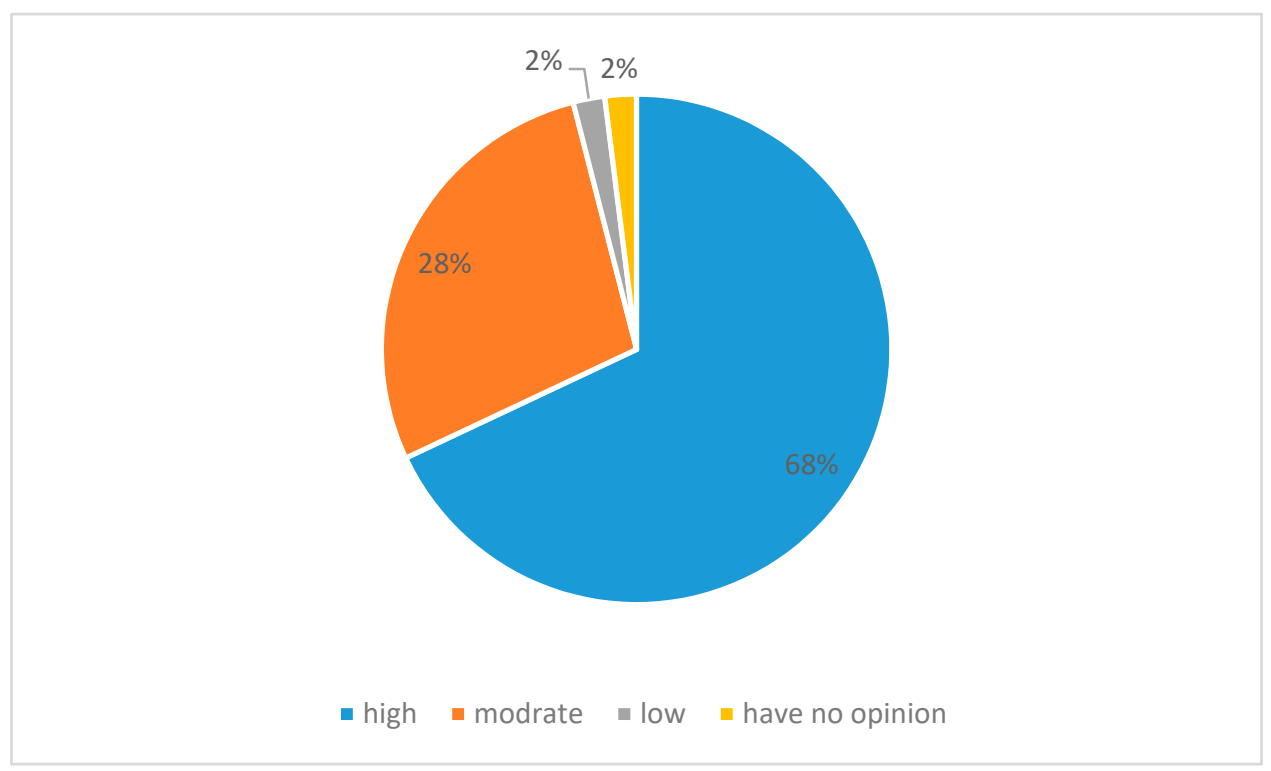

Figure 14. Tourist attractiveness of the park in the opinion of tourists.

Usually, attractiveness results from the possibility to practise active recreation, from attractive landscapes, specific natural values, or a widely understood authentic nature, which can be found in protected areas [111,166]. The opportunity to relax is also important [167]. It is also emphasized that the tourists' perception of park attractiveness is typically affected by more than one factor. It is not different for Gorczański National Park.

Among the positive opinions indicated in the survey, the following advantages appeared most often: sights, panoramas, varied trails, tranquillity, low traffic, favourable density of the trails, and interesting cultural and natural assets. Among the negative ones there were mud, lack of signposting and land development, insufficient care for tidiness on trails, and little variety of views as compared with the respondents' previous experiences from other national parks.

In an open question, the surveyed tourists had the opportunity to freely express their opinion about the park. Not surprisingly, this part contained more negative opinions. People paid attention to the garbage left by tourists on the trails and suggested that the number of trash bins be increased. It is worth reminding that too many trash bins contradict the idea of the park. The management are trying to foster a conscious tourist who takes back with them whatever they brought to the park. People complained about cars and quads running around the park and the buffer zone. Many tourists pointed out the development of the park and its growing popularity. They regretted it because they valued peace and quiet away from a crowd of tourists, which is so characteristic of the most popular parks in Poland.

The above opinions may indicate many of the park's deficiencies, so it is worth emphasizing the answers to the question related to recommending the park to others. The majority would strongly recommend a visit to Gorczański National Park to their friends. Positive perceptions of the visited national park or protected area generally prevail over neutral or negative ones. This is still an indirect evaluation of the park by visitors.

\section{Conclusions}

Owing to its specificity, Gorczański National Park is particularly attractive for weekend tourists, with all the consequences. First of all, its location-in the vicinity of larger urban areas-makes it a natural destination for their residents who are looking for a place for active recreation. The area of the Gorce Mts. is exactly such a place. Just over $70 \mathrm{~km}$ away, there is a region with almost no urbanization, with tranquillity undisturbed by civilization, clean air, and a beautiful landscape. 
Moreover, described in the literature as a set of features necessary for recreation [65], the analysed region offers favourable recreation conditions, such as special scenic qualities of the landscape, favourable bio-climatic conditions, or convenient amenities for active recreation [67]. An additional advantage, whose importance cannot be overestimated, is that this is a protected area. It is very important for tourism. As a result, visitors may rest assured that the resource they use (the main attraction, which is well preserved nature) will remain unchanged for many years and decades. The sustainability of the assets significantly increases the attractiveness of a protected area, and a higher form of protection in a region makes it more attractive. In this case, it is a national park, which is the highest form of conservation, regulated by a separate legal act. As a result, the park is a natural destination for many tourists interested in various forms of enjoying nature, ranging from active forms of recreation, such as trekking, cycling, and horse riding, to geotourism, a form of educational and cognitive tourism popular for the previous three decades. In recent years, the park has gained attention owing to its geotourist potential. Currently, $70 \%$ of the didactic routes present important geotourist features of the mountains. As part of the accompanying infrastructure, the number of facilities has increased where didactic activities related to animated and inanimate nature characteristic of the park are performed. A large number of scenic viewpoints perfectly introduce the geological and geomorphological context of the area to park visitors. All this translates into a strongly positive opinion on the park's attractiveness. The vast majority of tourists expressed a positive opinion about the park as a place of excellent active recreation. They understood the need for nature conservation in this place and supported activities aimed at promoting nature resources and the ways in which the park management tried to achieve the goals. The geotourist aspect is important for weekend tourists. Those who came here for a short time appreciated the peace, quiet, and adequate distribution of tourist traffic, so there was no issue of a large number of tourists on trails. This is often mentioned as one of the main attractiveness factors. It is coupled with a reduction in the number of investments-the respondents preferred nature preserved in an unchanged form to the development of, for example, ski infrastructure, destroying the attractive inanimate nature. Only $2 \%$ of the study subjects regretted the lack of development of this type of infrastructure.

It is also worth pointing at the applicability of the conducted research. It can serve as a reference point for the activities of the authorities managing the park, responsible also for preparing an attractive offer for the tourist traffic.

Generally, the study results confirm the correct direction of development of the tourist offer proposed by the park: The offer of trails and didactic routes was positively received. However, attention was drawn to important details that should be taken into account in order to increase the comfort of tourists visiting the examined protected area. It is worth considering the voices of older participants in the tourist traffic; in their opinion, the trails are difficult. Among other things, mud and stones make it problematic for this group to move. Considering the opinion of the senior group when preparing the offer may increase the overall attractiveness of the park. This is all the more important because the elderly tourist market is becoming an increasingly important segment every year, which should be recognized by all creators of tourist products or managers of regional tourist resources. It is worth emphasizing the importance of inanimate nature for tourists visiting the park. Values of this type were assessed as very attractive, so they can and should constitute a foundation for extending the tourist offer of the park.

On the other hand, significant participation of young people is important and consistent with a wider trend. Young tourists seem natural allies of the park managers in shaping the tourist offer, where conservation of natural resources is a priority. They understand the need of nature conservation even at the expense of their own comfort.

An important conclusion of the research is the educational attractiveness of the geotourist assets of the park, expressed by the high evaluation of the didactic routes set out in its area. As indicated by weekend tourists, geotourism, in addition to its sightseeing advantages, has also a significant educational value. 
In conclusion, Gorczański National Park turned out to be an area attractive for weekend tourists. It is an interesting destination in terms of natural resources, but also because of the form of nature conservation, which hopefully makes the resources, including geotourist ones, remain unchanged in their character for many more decades to come.

Finally, one should mention that the study limitations include the sample size. Although three different periods were chosen, which are generally popular among weekend tourists in Poland, the number of correct answers could have been higher. This is a recurring problem in field research. However, considering the fact that the study was survey-based, and that account was taken of the period during which the data were collected, one can assume that the results are representative. Weather conditions constituted another limitation: The timing of the surveys was set relatively early. The research was carried out in spite of the fact that weather conditions were not always favourable for weekend trips, which probably influenced the size of the studied group.

Author Contributions: Conceptualization, K.W.; methodology, K.W., S.J.; validation, K.W.; formal analysis, K.W.; investigation, P.O., A.R.; resources, P.O., A.Z., S.J.; data curation, P.O., A.Z.; writing-original draft preparation, K.W.; writing-review and editing, P.O., A.R., S.J.; supervision, K.W. All authors have read and agreed to the published version of the manuscript.

Funding: This research received no external funding.

Acknowledgments: The authors would like to thank Sabina Łanocha for her contribution to the research and article development.

Conflicts of Interest: The authors declare no conflict of interest.

\section{References}

1. Russell, M.A.; Bradford, J.E.; Murphy, L.E.E.C. Waters and development of a turn-of-the-century tourist economy in Yellowstone National Park. Hist. Archeol. 2004, 38, 96-113. [CrossRef]

2. Hunt, W.J., Jr. A Model of Tourism as Context for Historical Sites: An Example of Historical Archeology at Yellowstone National Park. In Historical Archeology of Tourism in Yellowstone National Park; Corbin, A., Russell, M.A., Eds.; Springer: New York, NY, USA, 2010; pp. 1-74.

3. Bergstrom, R.D.; Harrington, L.M.B. Embedded in nature: Challenges to sustainability in communities of the Greater Yellowstone ecosystem. Sustainability 2019, 11, 1459. [CrossRef]

4. Bushell, R.; Staiff, R.; Eagles, P.F.J. Tourism and Protected Areas: Benefits beyond Boundaries. In Tourism and Protected Areas: Benefits beyond Boundaries; Bushell, R., Eagles, P.F.J., Eds.; CABI: Wallingford, UK, 2007; pp. 1-11.

5. Kuenzi, C.; McNeely, J. Nature-Based Tourism. In Global Risk Governance; Renn, O., Walker, K.D., Eds.; IUCN Publishing: Gland, Switzerland, 2008; pp. 155-178.

6. Balmford, A.; Beresford, J.; Green, J.; Naidoo, R.; Walpole, M.; Manica, A. A global perspective of trends in nature-based tourism. PLoS Biol. 2009, 7, e1000144. [CrossRef] [PubMed]

7. Buckley, R. Ecotourism: Principles and Practises; CABI: Wallingford, UK, 2009.

8. Newsome, D.; Moore, S.A.; Dowling, R.K. Natural Area Tourism: Ecology, Impacts and Management, 2nd ed.; Channel View Publications: Bristol, UK, 2013.

9. Eagles, P.F.J. Research priorities in park tourism. J. Sustain. Tour. 2014, 22, 528-549. [CrossRef]

10. Garavaglia, V.G.; Diolaiuti, G.; Smiraglia, C.; Pasquale, V.; Pelfini, M. Evaluating tourist perception of environmental changes as a contribution to managing natural resources in glacierized areas: A case study of the Forni Glacier (Stelvio National Park, Italian Alps). Environ. Manag. 2012, 50, 1125-1138. [CrossRef] [PubMed]

11. Henriques, M.H.; Pena dos Reis, R.; Brilha, J.; Mota, T. Geoconservation as an emerging geoscience. Geoheritage 2011, 3, 117-128. [CrossRef]

12. Gray, M. Other nature: Geodiversity and geosystem services. Environ. Conserv. 2011, 38, 271-274. [CrossRef]

13. Burek, C.V.; Prosser, C.D. The history of geoconservation: An introduction. Geol. Soc. Lond. Spec. Publ. 2008, 300, 1-5. [CrossRef]

14. Gray, M. Geodiversity and Geoconservation: What, Why, and How? In Papers Presented at the George Wright Forum; Santucci, V.L., Ed.; Book Concern Printers: Hancock, MI, USA, 2005; pp. 4-12. 
15. Serrano, E.; González-Trueba, J.J. Assessment of geomorphosites in natural protected areas: The Picos de Europa National Park (Spain). Geomorphol. Relief Process. Environ. 2005, 11, 197-208. [CrossRef]

16. Lima, F.; Brilha, J.; Salamun, E. Inventorying geological heritage in large territories: A methodological proposal applied to Brazil. Geoheritage 2010, 2, 91-99. [CrossRef]

17. Fassoulas, C.; Mouriki, D.; Dimitriou-Nikolakis, P.; Iliopoulos, G. Quantitative assessment of geotopes as an effective tool for geoheritage management. Geoheritage 2012, 4, 177-193. [CrossRef]

18. Božić, S.; Tomić, N. Canyons and gorges as potential geotourism destinations in Serbia: Comparative analysis from two different perspectives-General tourists' and geotourists'. Open Geosci. 2015, 7, 531-546. [CrossRef]

19. Dowling, R.K.; Newsome, D. Geotourism: Sustainability, Impacts and Management; Elsevier: Oxford, UK, 2006.

20. Honey, M. Ecotourism and Sustainable Development: Who Own Paradise? 2nd ed.; Island Press: Washington, DC, USA, 2008.

21. Hose, T.A. Selling the story of Britain's stone. Environ. Interpret. 1995, 10, 16-17.

22. Panizza, M. Geomorphosites: Concepts, methods and example of geomorphological survey. Chin. Sci. Bull. 2001, 46, 4-6. [CrossRef]

23. Słomka, T.; Kicińska-Świderska, A. Geoturystyka-podstawowe pojęcia. Geoturystyka 2004, 1, 5-7.

24. Valentine, P.S. Review: Nature-based tourism. In Special Interest Tourism; Weiler, B., Hall, C.M., Eds.; Belhaven Press: London, UK, 1992; pp. 105-127.

25. Tonge, J.; Moore, S. Importance-satisfaction analysis for marine-park hinterlands: A Western Australian case study. Tour Manag. 2007, 28, 768-776. [CrossRef]

26. McIntosh, R.W.; Goeldner, C.R.; Ritchie, J.R.B. Tourism: Principles, Practices, Philosophies; Wiley: New York, NY, USA, 1995.

27. Ceballos-Lascurain, H. Tourism, Ecotourism and Protected Areas: The State of Nature-Based Tourism around the World and Guidelines for Its Development; IUCN: Cambridge, UK, 1996.

28. Bushell, B. Global issues for protected areas and nature-based tourism: Case studies of partnership in australia addressing some of these issues. In International Workshop: Case Studies on Sustainable Tourism and Biological Diversity; Gunling, L., Korn, H., Specht, R., Eds.; German Federal Agency for Nature Conservation: Bonn, Germany, 1999; pp. 93-114.

29. Priskin, J. Assessment of natural resources for nature-based tourism: The case of the Central Coast region of Western Australia. Tour Manag. 2001, 22, 637-648. [CrossRef]

30. Walpole, M.J. Feeding dragons in Komodo National Park: A tourism tool with conservation complications. Anim. Conserv. 2001, 4, 67-73. [CrossRef]

31. Walpole, M.J.; Goodwin, H.J. Local attitudes towards conservation and tourism around Komodo National Park, Indonesia. Environ. Conserv. 2001, 28, 160-166. [CrossRef]

32. Guyer, C.; Pollard, J. Cruise visitor impressions of the environment of the Shannon-Erne waterways system. J. Environ. Manag. 1997, 51, 199-215. [CrossRef]

33. Hose, T.A. Telling the story of stone-Assessing the client base. In Geological and Landscape Conservation; O'Halloran, D., Green, C., Harley, M., Stanley, M., Knill, S., Eds.; Geological Society: London, UK, 1994; pp. 451-457.

34. Hose, T.A. Geotourism-Selling the earth to europe. In Engineering Geology and the Environment; Marinos, P.G., Koukis, G.C., Tsiambaos, G.C., Stournaras, G.C., Eds.; Balkema: Rotterdam, The Netherlands, 1997; pp. 2955-2960.

35. Hose, T.A. Is it any fossicking good? Or behind the signs-A critique of current geotourism interpretative media. In Unpublished Paper Delivered to the Tourism in Geological Landscapes Conference; Ulster Museum: Belfast, UK, 1998.

36. Hose, T.A. European geotourism-Geological interpretation and geoconservation promotion for tourists. In Geological Heritage: Its Conservation and Management; Barretino, D., Wimbledon, W.P., Gallego, E., Eds.; Instituto Tecnologico Geominero de Espana: Madrid, Spain, 2000; pp. 127-146.

37. Hose, T.A. Towards a history of geotourism: Definitions, antecedents and the future. Geol. Soc. Lond. Spec. Publ. 2008, 300, 37-60. [CrossRef]

38. Hose, T.A.; Vasiljević, D.A. Defining the nature and purpose of modern geotourism with particular reference to the United Kingdom and South-East Europe. Geoheritage 2012, 4, 25-43. [CrossRef]

39. Newsome, D.; Dowling, R.K. Geotourism: The Tourism of Geology and Landscape; Goodfellow: Oxford, UK, 2010. 
40. Santangelo, N.; Romano, P.; Santo, A. Geo-itineraries in the Cilento Vallo di Diano Geopark: A tool for tourism development in southern Italy. Geoheritage 2015, 7, 319-335. [CrossRef]

41. Liddle, M.J. Recreation Ecology: The Ecological Impact of Outdoor Recreation and Ecotourism; Chapman and Hall: London, UK, 1997.

42. Newsome, D.; Moore, S.A.; Dowling, R.K. Natural Area Tourism: Ecology, Impacts and Management; Channel View Publications: Sydney, Australia, 2002.

43. Buckley, R. Impacts positive and negative: Links between ecotourism and environment. In Environmental Impacts of Ecotourism; Buckley, R., Ed.; CABI: New York, NY, USA, 2004; pp. 1-14.

44. Cole, D.N. Impacts of hiking and camping on soils and vegetation: A review. In Environmental Impacts of Ecotourism; Buckley, R., Ed.; CABI: Oxford, UK, 2004; pp. 41-60.

45. Newsome, D.; Cole, D.N.; Marion, J. Environmental impacts associated with recreational horse-riding. In Environmental Impacts of Ecotourism; Buckley, R., Ed.; CABI: New York, NY, USA, 2004; pp. 61-82.

46. Kelly, C.L.; Pickering, C.M.; Buckley, R.C. Impacts of tourism on threatened plant taxa and communities in Australia. Ecol. Manag. Restor. 2003, 4, 37-44. [CrossRef]

47. Pickering, C.M.; Hill, W. Impacts of recreation and tourism on plant biodiversity and vegetation in protected areas in Australia. J. Environ. Manag. 2007, 85, 791-800. [CrossRef]

48. Ballantyne, M.; Gudes, O.; Pickering, C.M. Visitor trails are an important cause of fragmentation in endangered urban forests. Landsc. Urban Plan. 2014, 130, 112-124. [CrossRef]

49. Godefroid, S.; Koedam, N. The impact of forest paths upon adjacent vegetation: Effects of the path surfacing material on the species composition and soil compaction. Biol. Conserv. 2004, 119, 405-419. [CrossRef]

50. Hill, W.; Pickering, C.M. Vegetation associated with different walking track types in the Kosciuszko Alpine area, Australia. J. Environ. Manag. 2006, 78, 24-34. [CrossRef]

51. Wimpey, J.; Marion, J.L. The influence of use, environmental and managerial factors on the width of recreational trails. J. Environ. Manag. 2010, 91, 2028-2037. [CrossRef]

52. Kutiel, P.; Zhevelev, H.; Harrison, R. The effect of recreational impacts on soil and vegetation of stabilised Coastal Dunes in the Sharon Park, Israel. Ocean Coast. Manag. 1999, 42, 1041-1060. [CrossRef]

53. Marion, J.L.; Leung, Y.F. Trail resource impacts and an examination of alternative assessment techniques. J. Park Recreat. Adm. 2001, 19, 17-37.

54. Monz, C.A.; Cole, D.N.; Leung, Y.F.; Marion, J.L. Sustaining visitor use in protected areas: Future opportunities in recreation ecology research based on the USA experience. Environ. Manag. 2010, 45, 551-562. [CrossRef] [PubMed]

55. Marion, J.L.; Wimpey, J.F.; Park, L.O. The science of trail surveys: Recreation ecology provides new tools for managing wilderness trails. Park Sci. 2011, 28, 60-65.

56. Fenu, G.; Cagoni, D.; Ulian, T.; Bacchetta, G. The impact of human trampling on a threatened coastal Mediterranean plant: The case of Anchusa littorea Moris (Boraginaceae). Flora 2013, 208, 104-110. [CrossRef]

57. McCool, S.F. Constructing partnerships for protected area tourism planning in an era of change and messiness. J. Sustain. Tour. 2009, 17, 133-148. [CrossRef]

58. Panizza, M.; Piacente, S. Geomorfologia Culturale; Pitagora Editrice: Bologna, Italy, 2003.

59. Kondracki, J. Geografia Regionalna Polski; PWN: Warszawa, Poland, 2000.

60. Ordinance of the Council of Ministers of August 8, 1980 on the creation of the Gorczański National Park. Journal of Laws, 22 August 1980.

61. Kruczek, Z. Atrakcje Turystyczne. Fenomen, Typologia, Metody Badań; Proksenia: Kraków, Poland, 2011.

62. Lijewski, T.; Mikułowski, B.; Wyrzykowski, J. Geografia Turystyki Polski; Polskie Wydawnictwo Ekonomiczne: Warszawa, Poland, 1998.

63. Warszyńska, J.; Jackowski, A. Podstawy Geografii Turyzmu; PWN: Warszawa, Poland, 1978.

64. Rogalewski, O. Zagospodarowanie Turystyczne; WSiP: Warszawa, Poland, 1979.

65. Lijewski, T.; Mikułowski, B.; Wyrzykowski, J. Geografia Turystyki Polski; Polskie Wydawnictwo Ekonomiczne: Warszawa, Poland, 2002.

66. Kowalczyk, A. Geografia Turyzmu; PWN: Warszawa, Poland, 2001.

67. Lijewski, T.; Mikułowski, B.; Wyrzykowski, J. Geografia Turystyki Polski, 5th ed.; Polskie Wydawnictwo Ekonomiczne: Warszawa, Poland, 2008. 
68. Cieszkowski, M.; Chodyń, R.; Szczęch, M. Gorce-Góry fliszowe. In Gorczański Park Narodowy. Przyroda $i$ Krajobraz Pod Ochrona; Czarnota, P., Stefanik, M., Eds.; Gorczański Park Narodowy: Poręba Wielka, Poland, 2015; pp. 39-51.

69. Pawlik, Ł.; Šamonil, P.; Malik, I.; Kroh, P.; Ślęzak, A.; Danĕk, P. Geomorphic edge effects in response to abiotic and anthropogenic disturbances in forest ecosystems of the Gorce Mountains, Western Carpathians. Catena 2019, 177, 134-148. [CrossRef]

70. Andreucci, B.; Castelluccio, A.; Jankowski, L.; Mazzoli, S.; Szaniawski, R.; Zattin, M. Burial and exhumation history of the Polish Outer Carpathians: Discriminating the role of thrusting and post-thrusting extension. Tectonophys 2013, 608, 866-883. [CrossRef]

71. Gorczański Park Narodowy. Przyroda Nieożywiona. Available online: https://www.gorczanskipark.pl/page, art,id,11,kategoria,Przyroda_nieozywiona.html (accessed on 15 November 2019).

72. Cieszkowski, M. Geologiczne walory naukowe Gorczańskiego Parku Narodowego i jego otoczenia. Ochr. Besk. Zach. 2006, 1, 45-57.

73. Szczęch, M.; Cieszkowski, M.; Chodyń, R.; Loch, J. Geotouristic values of the Gorce National Park and its surroundings (the Outer Carpathians, Poland). Geotourism 2016, 1-2, 27-44. [CrossRef]

74. Chowaniec, J.; Poprawa, D.; Witek, K. Stop E8-Rabka: Wody mineralne. In Carpatian Paleogeography and Geodynamics: A Multidisciplinary Approach. Field Trip Guide, Proceedings of the 12th Meeting of the Association of European Geological Societies, Kraków, Poland, 10-15 September 2001; Birkenmajer, K., Krobicki, M., Eds.; Państwowy Instytut Geologiczny: Kraków, Poland, 2001; pp. 121-125.

75. Chowaniec, J.; Poprawa, D.; Witek, K. Występowanie wód termalnych w polskiej części Karpat. Przegl. Geol. 2001, 49, 728-742.

76. Statistics Poland. Ochrona Środowiska 2018; Statistics Poland: Warsaw, Poland, 2018.

77. Statistics Poland. Ochrona Środowiska 2011; Statistics Poland: Warsaw, Poland, 2011.

78. Statistics Poland. Ochrona Środowiska 2012; Statistics Poland: Warsaw, Poland, 2012.

79. Statistics Poland. Ochrona Środowiska 2013; Statistics Poland: Warsaw, Poland, 2013.

80. Statistics Poland. Ochrona Środowiska 2014; Statistics Poland: Warsaw, Poland, 2014.

81. Statistics Poland. Ochrona Środowiska 2015; Statistics Poland: Warsaw, Poland, 2015.

82. Statistics Poland. Ochrona Środowiska 2016; Statistics Poland: Warsaw, Poland, 2016.

83. Statistics Poland. Ochrona Środowiska 2017; Statistics Poland: Warsaw, Poland, 2017.

84. Kruczek, Z. Frekwencja w polskich atrakcjach turystycznych. Problemy oceny liczby odwiedzających. Ekon. Probl. Turyst. 2016, 3, 25-35. [CrossRef]

85. Partyka, J. Ruch turystyczny w polskich parkach narodowych. Folia Turist. 2010, 22, 9-23.

86. Baraniec, A. Turystyka w Babiogórskim Parku Narodowym. In Użytkowanie Turystyczne Parków Narodowych; Partyka, J., Ed.; Wydawnictwo Ojcowski Park Narodowy: Ojców, Poland, 2002; pp. 155-165.

87. Wieniawska, B. Turystyka a ochrona przyrody w Karkonoskim Parku Narodowym. In Użytkowanie Turystyczne Parków Narodowych; Partyka, J., Ed.; Wydawnictwo Ojcowski Park Narodowy: Ojców, Poland, 2002; pp. 259-270.

88. Fidelus, J. Turystyka piesza i jej wpływ na przemiany rzeźby terenu w otoczeniu hal Gąsienicowej i Kondratowej w Tatrach. In Stan i Perspektywy Rozwoju Turystyki w Tatrzańskim Parku Narodowym; Pociask-Karteczka, J., Matuszyk, A., Skawiński, P., Eds.; AWF: Kraków, Poland, 2007; pp. 261-272.

89. Act of April 16, 2004 on nature conservation. Journal of Laws, No. 92, Item 880, Art. 5. Available online: http://prawo.sejm.gov.pl/isap.nsf/DocDetails.xsp?id=WDU20040920880 (accessed on 10 December 2019).

90. Conservation Plan for Gorczański National Park of 2018. Available online: https://www.gorczanskipark. pl/UserFiles/File/2018/BIP\%20i\%20ogloszenia/PROJEKT\%20\%20z\%2015-01-2018\%20Planu\%20Ochrony\% 20GPN.pdf (accessed on 27 November 2019).

91. Beerli, A.; Martín, D. Tourists characteristics and the perceived image of tourists destination: A quantitative analysis of a case study of Lanzarote, Spain. Tour Manag. 2004, 25, 623-636. [CrossRef]

92. Togridou, A.; Hovardas, T.; Pantis, J.D. Determinants of visitors willingness to pay for the National Marine Park of Zakynthos, Greece. Ecol. Econ. 2006, 60, 308-319. [CrossRef]

93. Ceurvorst, R.; Lamborn, C. Visitor attitudes and value orientations for a proposed national monument. J. Outdoor Recreat. Tour. 2018, 23, 33-43. [CrossRef] 
94. Mmopelwa, G.; Kgathi, D.L.; Molefhe, L. Tourists' perceptions and their willingness to pay for park fees: A case study of self-drive tourists and clients for mobile tour operators in Moremi Game Reserve, Botswana. Tour Manag. 2007, 28, 1044-1056. [CrossRef]

95. Jones, N.; Panagiotidou, K.; Spilanis, I.; Evangelinos, K.; Dimitrakopoulos, P. Visitors' perceptions on the management of an important nesting site for loggerhead sea turtle (Caretta caretta L.): The case of Rethymno coastal area in Greece. Ocean Coast. Manag. 2011, 54, 577-584. [CrossRef]

96. Lili, P.; Lijuan, C.; Ming, W. Tourist behaviors in Wetland Park: A preliminary study in Xixi National Wetland Park, Hangzhou, China. Chin. Geogr. Sci. 2010, 20, 66-73.

97. Beh, A.; Bruyere, B. Segmentation by visitor motivation in three Kenyan national reserves. Tour Manag. 2007, 28, 1464-1471. [CrossRef]

98. Ehrenfeld, D. The conservation of non-resources. Am. Sci. 1976, 64, 648-656.

99. Ferreira, S.; Harmse, A. Kruger National Park: Tourism development and issues around the management of large numbers of tourists. J. Ecotour. 2014, 13, 16-34. [CrossRef]

100. Adams, C.; Seroa da Motta, R.; Ortiz, A.; Reid, J.; Aznar, E.; Sinisgalli, A. The use of contingent valuation for evaluating protected areas in the developing world: Economic valuation of Morro do Diabo State Park, Atlantic Rainforest, São Paolo State (Brazil). Ecol. Econ. 2008, 66, 359-370. [CrossRef]

101. Duzgunes, E.; Demirel, O. Determining the tourism potential of the Altindere Valley National Park (Trabzon/Turkey) with respect to its conservation value. Int. J. Sustain. Dev. World Ecol. 2013, 20, 358-368. [CrossRef]

102. Mayer, M. Can nature-based tourism benefits compensate for the costs of national parks? A study of the Bavarian Forest National Park, Germany. J. Sustain. Tour. 2014, 22, 561-583. [CrossRef]

103. Reimann, M.; Lamp, M.-L.; Palang, H. Tourism impacts and local communities in Estonian National Parks. Scand. J. Hosp. Tour. 2011, 11, 87-99. [CrossRef]

104. Strickland-Munro, J.; Moore, S. Indigenous involvement and benefits from tourism in protected areas: A study of Purnululu National Park and Warmun Community, Australia. J. Sustain. Tour. 2013, 21, $26-41$. [CrossRef]

105. Muller, M.; Job, H. Managing natural disturbance in protected areas: Tourists' attitude towards the bark beetle in a German national park. Biol. Conserv. 2009, 142, 375-383. [CrossRef]

106. Oh, C.O.; Draper, J.; Dixon, A.W. Comparing resident and tourist preferences for public beach access and related amenities. Ocean Coast. Manag. 2010, 53, 245-251. [CrossRef]

107. Peters, H.; Hawkins, J.P. Access to marine parks: A comparative study in willingness to pay. Ocean Coast. Manag. 2009, 52, 219-228. [CrossRef]

108. Petrosillo, I.; Zurlini, G.; Corliano, M.E.; Zacarrelli, E.; Dadamo, M. Tourist perception of recreational environment and management in a marine protected area. Landsc. Urban Plan. 2007, 79, 29-37. [CrossRef]

109. Buultjens, J.; Ratnayake, I.; Gnanapala, A.; Aslam, M. Tourism and its implications for management in Ruhuna National Park (Yala), Sri Lanka. Tour Manag. 2005, 26, 733-742. [CrossRef]

110. Cunha, A.A. Negative effects of tourism in a Brazilian Atlantic forest National Park. J. Nat. Conserv. 2010, 18, 291-295. [CrossRef]

111. Haukeland, J.V.; Grue, B.; Veisten, K. Turning national parks into tourism attractions: Nature orientation and quest for facilities. Scand. J. Hosp. Tour. 2010, 10, 248-271. [CrossRef]

112. Fleishman, L.; Feitelson, E.; Salomon, I. The role of cultural and demographic diversity in crowding perception: Evidence from nature reserves in Israel. Tour. Anal. 2004, 9, 23-40. [CrossRef]

113. Oku, H.; Fukamachi, K. The differences in scenic perception of forest visitors through their attributes and recreational activity. Landsc. Urban Plan. 2006, 75, 34-42. [CrossRef]

114. Arnberger, A.; Brandenburg, C. Past on-site experience, crowding perceptions, and use displacement of visitor groups to a periurban national park. Environ. Manag. 2007, 40, 34-45. [CrossRef]

115. Arnberger, A.; Haider, W. A comparison of global and actual measures of perceived crowding of urban forest visitors. J. Leis. Res. 2007, 39, 668-685. [CrossRef]

116. Leujak, W.; Ormond, R.F.G. Visitor perceptions and the shifting social carrying capacity of south Sinai's coral reefs. Environ. Plan. 2007, 39, 472-489. [CrossRef]

117. Uysal, M.; Jurowski, C.; Noe, F.P.; McDonald, C.D. Environmental attitude by trip and visitor characteristics-US Virgin Islands National Park. Tour Manag. 1994, 15, 284-294. [CrossRef] 
118. Puhakka, R. Environmental concern and responsibility among nature tourists in Oulanka PAN Park, Finland. Scand. J. Hosp. Tour. 2011, 11, 76-96. [CrossRef]

119. Dunlap, R.E.; Van Liere, K.D.; Mertig, A.G.; Jones, R.E. Measuring endorsement of the new ecological paradigm: A revised NEP scale. J. Soc. Issues 2000, 56, 425-442. [CrossRef]

120. Akama, J.S.; Land, C.L.; Burnett, G.W. Conflicting attitudes toward state wildlife conservation programs in Kenya. Soc. Nat. Resour. 1995, 8, 133-144. [CrossRef]

121. Infield, M. Attitudes of rural communities towards conservation and local conservation areas in Natal, South Africa. Biol. Conserv. 1988, 45, 21-46. [CrossRef]

122. Newmark, W.D.; Leonard, N.L.; Sariko, H.I.; Gamassa, D.M. Conservation attitudes of local people living adjacent to five protected areas in Tanzania. Biol. Conserv. 1993, 63, 177-183. [CrossRef]

123. Trakolis, D. Local people's perceptions of planning and management issues in Prespes Lakes National Park, Greece. J. Environ. Manag. 2001, 61, 227-241. [CrossRef]

124. Hall, T.; Shelby, B. Temporal and spatial displacement: Evidence from a high-use reservoir and alternative sites. J. Leis. Res. 2000, 32, 435-456. [CrossRef]

125. Manning, R.E.; Valliere, W.A. Coping in outdoor recreation: Causes and consequences of crowding and conflict among community residents. J. Leis. Res. 2001, 33, 410-426. [CrossRef]

126. Balmford, A.; Green, J.M.H.; Anderson, M.; Beresford, J.; Huang, C.; Naidoo, R.; Manica, A. Walk on the wild side: Estimating the global magnitude of visits to protected areas. PLoS Biol. 2015, 13, e1002074. [CrossRef]

127. Kretchaman, J.; Eagles, P. An analysis of the motives of ecotourists in comparison to the general Canadian population. Soc. Leis. 1990, 13, 499-508. [CrossRef]

128. Eagles, P.F. The travel motivations of Canadian ecotourists. J. Travel Res. 1992, 31, 3-7. [CrossRef]

129. Wright, P.A. North American ecotourism markets: Motivations, preferences, and destinations. J. Travel Res. 1996, 35, 3-10.

130. Palacio, V.; McCool, S.F. Identifying ecotourists in Belize through benefit segmentation: A preliminary analysis. J. Sustain. Tour. 1997, 5, 234-243. [CrossRef]

131. Chan, J.K.L.; Baum, T. Motivation factors of ecotourists in ecolodge accommodation: The push and pull factors. Asia Pac. J. Tour. Res. 2007, 12, 349-364. [CrossRef]

132. Dodds, R.; Graci, S.R.; Holmes, M. Does the tourist care? A comparison of tourists in Koh Phi Phi, Thailand and Gili Trawangan, Indonesia. J. Sustain. Tourism. 2010, 18, 207-222. [CrossRef]

133. Butler, R.; Boyd, S. (Eds.) Tourism and National Parks: Issues and Implications; Wiley: Chichester, UK, 2000.

134. McCool, S.F. Managing for visitor experiences in protected areas: Promising opportunities and fundamental challenges. PARKS Int. J. Prot. Areas Manag. 2006, 16, 3-9.

135. Arabatzis, G.; Grigoroudis, E. Visitors' satisfaction, perceptions and gap analysis: The case of Dadia-Lefkimi-Souflion National Park. Landsc. Urban Plan. 2010, 97, 229-238. [CrossRef]

136. Suckall, N.; Fraser, E.D.G.; Cooper, T.; Claire, Q. Visitor perceptions of rural landscapes: A case study in the Peak District National Park, England. J. Environ. Manag. 2009, 90, 1195-1203. [CrossRef]

137. Andersson, T.D. The tourist in the experience economy. Scand. J. Hosp. Tour. 2007, 7, 46-58. [CrossRef]

138. Larsen, S. Aspects of a psychology of the tourist experience. Scand. J. Hosp. Tour. 2007, 7, 7-18. [CrossRef]

139. Ritchie, J.R.; Hudson, S. Understanding and meeting the challenges of consumer/tourist experience research. Int. J. Tour. Res. 2009, 11, 111-126. [CrossRef]

140. Pine, B.J.; Gilmore, J.H. Welcome to experience economy. Harv. Bus. Rev. 1998, 74, 97-105.

141. Bansal, H.; Eiselt, H.A. Exploratory research of tourists' motivations and planning. Tour Manag. 2004, 25, 387-396. [CrossRef]

142. Kim, J.H.; Ritchie, B.W. Motivation-based typology: An empirical study of golf tourists. J. Hosp. Tour. Res. 2012, 36, 251-280. [CrossRef]

143. Luo, Y.; Deng, J. The new environmental paradigm and nature-based tourism motivation. J. Travel Res. 2008, 46, 392-402. [CrossRef]

144. Kim, H.; Borges, M.C.; Chon, J. Impacts of environmental values on tourism motivation: The case of FICA, Brazil. Tour Manag. 2006, 27, 957-967. [CrossRef]

145. Yuan, S.; McDonald, C. Motivational determinants of international pleasure time. J. Travel Res. 1990, 29, 42-44. [CrossRef]

146. Oh, H.; Fiore, A.M.; Jeoung, M. Measuring experience economy concepts: Tourism applications. J. Travel Res. 2007, 46, 119-132. [CrossRef] 
147. Hovardas, T.; Poirazidis, K. Evaluation of the environmentalist dimension of ecotourism at the Dadia Forest Reserve (Greece). Environ. Manag. 2006, 38, 810-822. [CrossRef]

148. Hall, C.M. Tourism and biodiversity: More significant than climate change? J. Herit. Tours 2010, 5, $253-266$. [CrossRef]

149. Wahlers, R.G.; Etzel, M.J. Vacation preferences as a manifestation of optimal stimulation and lifestyle experience. J. Leis. Res. 1985, 17, 283-295. [CrossRef]

150. Ross, E.D.; Iso-Ahola, S.E. Sightseeing tourists motivation and satisfaction. Ann. Tour. Res. 1991, 18, $226-237$. [CrossRef]

151. Sickle Van, K.; Eagles, P.F.J. Budgets, pricing policies and user fees in Canadian parks' tourism. Tour Manag. 1998, 19, 225-235. [CrossRef]

152. Scott, D.; Jones, B.; Konopek, J. Implications of climate and environmental change for nature-based tourism in the Canadian Rocky Mountains: A case study of Waterton Lakes National Park. Tour Manag. 2007, 28, 570-579. [CrossRef]

153. Jacobsen, J.; Steen, K. Use of landscape perception methods in tourism studies: A review of photo-based research approaches. Tour. Geogr. 2007, 9, 234-253. [CrossRef]

154. Zube, E.H. Local and extra-local perceptions of national parks and protected areas. Landsc. Urban Plan. 1986, 13, 11-17. [CrossRef]

155. Hsu, T.-K.; Tsai, Y.-F.; Wu, H.-H. The preference analysis for tourist choice of destination: A case study of Taiwan. Tour Manag. 2009, 30, 288-297. [CrossRef]

156. Little, C. Greenways for America; Johns Hopkins University Press: Baltimore, MD, USA, 1990.

157. Tilden, F. Interpreting Our Heritage, rev. ed.; University of North Carolina Press: Chapel Hill, NC, USA, 1977.

158. Goldman, T.L.; Chen, W.J.; Larsen, D.L. Clicking the icon: Exploring the meanings visitors attach to three national capital memorials. J. Interpret. Res. 2001, 6, 3-30.

159. Füller, J.; Matzler, K. Customer delight and market segmentation: An application of the three-factor theory of customer satisfaction on life style groups. Tour Manag. 2008, 29, 116-126. [CrossRef]

160. Hui, T.K.; Wan, D.; Ho, A. Tourists' satisfaction, recommendation and revisiting Singapore. Tour Manag. 2007, 28, 965-975. [CrossRef]

161. Matzler, K.; Füller, J.; Faullant, R. Customer satisfaction and loyalty to Alpine ski resorts: The moderating effect of lifestyle, spending and customers' skiing skills. Int. J. Tour. Res. 2007, 9, 409-421. [CrossRef]

162. Petrick, J.F. Measuring cruise passengers' perceived value. Tour. Anal. 2003, 7, 251-258. [CrossRef]

163. Sadeh, E.; Asgari, F.; Mousavi, L.; Sadeh, S. Factors affecting tourist satisfaction and its consequences. J. Basic Appl. Sci. Res. 2012, 2, 1557-1560.

164. Gursoy, D.; Mccleary, K.W.; Lepsito, L.R. Propensity to complain: Effects of personality and behavioral factors. J. Hosp. Tour. Res. 2007, 31, 358-386. [CrossRef]

165. Tsiotsou, R.; Vasioti, E. Satisfaction: A segmentation criterion for "short term" visitors of mountainous destinations. J. Travel Tour. Market. 2006, 20, 61-73. [CrossRef]

166. Raadik, J.; Cottrell, S.P.; Fredman, P.; Ritter, P.; Newman, P. Understanding recreational experience preferences: Application at Fulufjället National Park, Sweden. Scand. J. Hosp. Tour. 2010, 10, 231-247. [CrossRef]

167. Yoon, Y.; Uysal, M. An examination of the effects of motivation and satisfaction on destination loyalty: A structural model. Tour Manag. 2005, 26, 45-56. [CrossRef]

(C) 2020 by the authors. Licensee MDPI, Basel, Switzerland. This article is an open access article distributed under the terms and conditions of the Creative Commons Attribution (CC BY) license (http://creativecommons.org/licenses/by/4.0/). 